Article

\title{
Developing Sustainable City Indicators for Cambodia through Delphi Processes of Panel Surveys
}

\author{
Puthearath Chan $1,2, *$ (1) and Myeong-Hun Lee ${ }^{2, *}$ \\ 1 Office of Sustainable Lifestyle, Ministry of Environment, 503 Tonle Bassac, Chamkarmon, \\ Phnom Penh 12301, Cambodia \\ 2 Graduate School of Urban Studies, Hanyang University, 222 Wangsimni-ro, Seongdong-gu, \\ Seoul 04763, Korea \\ * Correspondence: cptr5@hanyang.ac.kr (P.C.); mhlee99@hanyang.ac.kr (M.-H.L.); \\ Tel.: +855-11-660-040 (P.C.); +82-10-7722-0987 (M.-H.L.)
}

Received: 8 May 2019; Accepted: 31 May 2019; Published: 5 June 2019

check for updates

\begin{abstract}
Currently, Cambodia does not have sustainable city indicators, and green and clean city indicators are also limited compared to UN Sustainable Development Goal 11 (SDG 11) indicators. Therefore, this research aims to develop sustainable city indicators for Cambodia and to address the questions "Are the green and clean city indicators limited in terms of sustainability?" and "Are the UN SDG 11 indicators suitable for Cambodia?" Delphi processes of panel surveys were conducted to develop the indicators in Round 1, pre-validate the indicators in Round 2, and validate the indicators in Round 3. The results showed that 69 initial indicators were obtained from Round 1; 41 pre-validated indicators were obtained from Round 2; and finally, 32 validated indicators were obtained from Round 3. All of the 32 indicators reached consensus. Based on the consensus indicators, the green and clean city indicators were found to be limited in terms of sustainability, and the UN SDG 11 has nine indicators suitable for Cambodia. These findings could be useful for applying the UN SDG 11 indicators to Cambodia and transforming the green and clean city indicators to sustainable city indicators. The 32 consensus indicators could be used as alternative sustainable city indicators for Cambodia.
\end{abstract}

Keywords: UN Sustainable Development Goal 11; ASEAN Environmentally Sustainable City; Cambodia city indicators; sustainable city indicators; Delphi processes of panel surveys

\section{Introduction}

Following global trends on low-carbon development, Cambodia produced the national green growth roadmap in 2009 (published in 2010) to suggest the win-win-win situations between the economy, environment, and society in order to achieve stable economic growth, environmental sustainability, and human well-being [1,2]. In 2012, Cambodia, after signing the agreement to establish the Global Green Growth Institute (GGGI) as an international organization (headquarters in Seoul) with fifteen other founding member countries at the United Nations Conference on Sustainable Development in Brazil [3,4], established the National Council on Green Growth (NCGG) to coordinate the low-carbon development of the country [5]. In 2013, the government approved the national policy and national strategic plan on green growth 2013-2030 to promote sustainable long-term economic, environmental, and social development in Cambodia [6,7].

With the new agenda on sustainable development goals of the United Nations (UN SDGs), Cambodia established the National Council for Sustainable Development (NCSD) in 2015 by combining the NCGG with other relevant institutions to promote the sustainable development in Cambodia [8]. In August 2016, Minister of Environment as the Chair of NCSD argued in the green city strategic 
planning methodology document that "The development of green and sustainable cities in Cambodia is a key policy priority for the NCSD" [9] (p. iv). Furthermore, the government through its NCSD is currently developing the Code for Environment and Natural Resources. One chapter of the Code titled Sustainable Cities (Chapter 4) [10] is specifically to deal with the UN SDG 11 "Make cities and human settlements inclusive, safe, resilient, and sustainable" [11-14]. Moreover, Cambodia launched the clean city standard in order to improve urban quality and development by monitoring and evaluating cities through a clean city contest every three years [15], as well as the green city development program. The goal is to develop cities to be clean, green, and competitive while offering a safe and quality lifestyle to its residents $[9,16,17]$.

Based on the above reviewed sustainable city governance and development progress, Cambodia currently does not have indicators to monitor and assess the development of sustainable cities yet. Therefore, this research firstly aims to develop sustainable city indicators for Cambodia. The concept of sustainable development comprises three dimensions: Economic, social, and environmental [18-22]. The development must integrate the overlapping intersections of these dimensions, such as equitable (interaction between the economic and social dimension), liveable (correspondence of the environment to social needs), and viable [23-26] (economic development must abide by the supportive capacity of the ecosystems, and depletion of non-renewable resources must be avoided) [23] (p. 407). In this sense, sustainable city indicators need to be reached not only in terms of environmental dimensions, but also social and economic dimensions, especially the overlapping intersections of these dimensions. The UN SDG 11 is known as a global sustainable city goal-it is probably sufficient for all these dimensions, but Cambodia's green and clean city indicators are limited compared to this goal's indicators (Table 1) [27-33]. This difference raises a number of questions. Does it mean that green and clean city indicators are limited in terms of sustainability? Moreover, as the UN SDG 11 indicators were developed to be applied worldwide, it is unclear whether they are suitable for the Cambodia context? Therefore, this research also sought to answer these questions. In addition, how the green and clean city and UN SDG 11 indicators are limited or suitable for Cambodia in terms of sustainability will be investigated.

\section{Materials and Methods}

\subsection{Method Selection}

Multi-criteria decision analysis (MCDA) is an umbrella term to describe a collection of formal approaches that take account of multiple criteria in helping individuals or groups explore decisions that matter. These techniques are widely used in fields related to qualitative assessment [34-39]. In many studies, MCDA techniques, such as Multi-Attribute Utility Theory (MAUT), Analytic Network Process (ANP), Measuring Attractiveness by a Categorical Based Evaluation (MACBETH), Analytic Hierarchy Process (AHP), and Technique for Order of Preference by Similarity to Ideal Solution (TOPSIS) are used in selecting, ranking, and/or prioritizing issues, such as policies, criteria, index, and indicators [40-47]. Among these, ANP and AHP are increasingly popular for use in prioritizing issues known as weight analysis through pairwise comparison [48-51].

Quite commonly, ANP and AHP are used as combined methods with other MCDA techniques, such as Delphi. In this case, Delphi plays a role in developing issues whereas ANP or AHP play a role in prioritizing the issues developed by Delphi [52-55]. Furthermore, Delphi itself has special characteristics to firstly develop the issues that are not available or need to be improved, such as the criteria, index, and indicators, and then validating the developed issues by identifying and confirming the level of importance. More recently, Delphi has been widely used to develop the criteria and indicators in many fields, especially in construction fields [56-62]; for example, Sourani and Sohail (2015) [63] used the Delphi technique to develop an agreed set of economic sustainability criteria that should be addressed in a procumbent strategy. Moreover, many studies [63-77] have showed that Delphi can be useful to (a) obtain accurate information that is unavailable, (b) handle complex 
problems that require more judgmental analysis, (c) define areas where there is considerable uncertainty and/or a lack of agreed knowledge or disagreement, (d) allow for combining fragmentary perspectives into a collective understanding, (e) model a real world phenomena involving a range of viewpoints and for which there is little established quantitative evidence, and (f) highlight topics of concern and assess uncertainty in a quantitative manner. In particular, based on the summary explained in Appendix A [78-84], this research accordingly chose the Delphi technique to develop sustainable city indicators (SCIs) for Cambodia through three-round panel surveys. Delphi Round 1 initially developed the indicators. Delphi Round 2 identified the level of importance (pre-validated the indicators). Delphi Round 3 confirmed the level of importance (validated the indicators).

\subsection{Framework Initiation}

This research firstly reviewed Cambodia-related sustainable city indicators, such as UN SDG 11 (globally related), ASEAN Environmentally Sustainable City (regionally related), and Korean HAN indicators (case study-related), and domestic green and clean city (GC and CC) indicators. Secondly, the reviewed indicators were classified based on their similarity and correlation into relative categories for developing questionnaires for a Delphi panel survey in Round 1. Thirdly, the round-one Delphi process of the panel survey was conducted to initially develop sustainable city indicators. The initial indicators were developed as follows: (1) Similar or same input indicators were combined into one (the results are shown in the frequency of the panelists providing same indicators); and (2) measurement-lacked indicators were supplemented based on the measurements of the reviewed indicators. Fourthly, the round-two Delphi process of the panel survey was conducted to identify the level of importance of the indicators (to pre-validate the indicators). Fifthly, the round-three Delphi process of the panel survey was conducted to confirm the level of importance of the indicators (to validate the indicators). Finally, the consensus was analyzed after the level of importance confirmed. The research flow is illustrated in Figure 1.

\subsection{Relevant Indicator Selection, Review, and Classification}

As mentioned in Section 2.2, this research selected, reviewed, and classified the five major sources of the indicators as follows:

(1) UN Sustainable Development Goals (SDGs) are a major step forward and an improvement on the Millennium Development Goals (MDGs) [11,85] and agreed in the UN 2030 Agenda for Sustainable Development. The SDGs addressed 17 goals and 169 targets [86-89]. The goal 11 addressed 10 targets, and its indicators were reviewed in Table 1 in the column 'SDG 11' [30,31].

(2) ASEAN Environmentally Sustainable City (ESC) is the initiative of ASEAN, the Association of Southeast Asian Nations (Brunei, Cambodia, Indonesia, Laos, Malaysia, Myanmar, Philippines, Singapore, Thailand, and Vietnam), which was endorsed by the ASEAN Environment Ministers in 2005 in order to pursue environmental sustainability in the rapidly-growing cities of ASEAN [90]. The ESC indicators were reviewed in Table 1 in the column 'ESC' [91].

(3) Korean HAN refers to the Korean case study indicators, which were developed by Sang-mi Han and Myeong-hun Lee [92]. This research developed indicators based on the UN Sustainable Development Goal 11 indicators, HABITAT indicators and Korea's relevant indicators. The developed indicators were reviewed in Table 1 in the column 'HAN'.

(4) GC refers to the green city development project in Cambodia. The government through its NCSD implemented the project named 'Green Urban Development Program' with the support from GGGI and produced the green city strategic planning methodology [9] and green city strategic plan for Phnom Penh 2017 to 2026 [16]. The indicators attached with their sectoral objectives were reviewed in Table 1 in the column 'GC' [16].

(5) CC refers to the clean city standard of Cambodia produced by the National Committee for Clean City Assessment in order to monitor and evaluate the cities through a clean city contest every 
three years. The winning cities will be awarded by the Prime Minister of Cambodia in the following three names 'Clean City Romduol I, II, and III' upon the winning score [32,33]. The CC indicators were reviewed in Table 1 in the column ' $\mathrm{CC}$ ' [15].

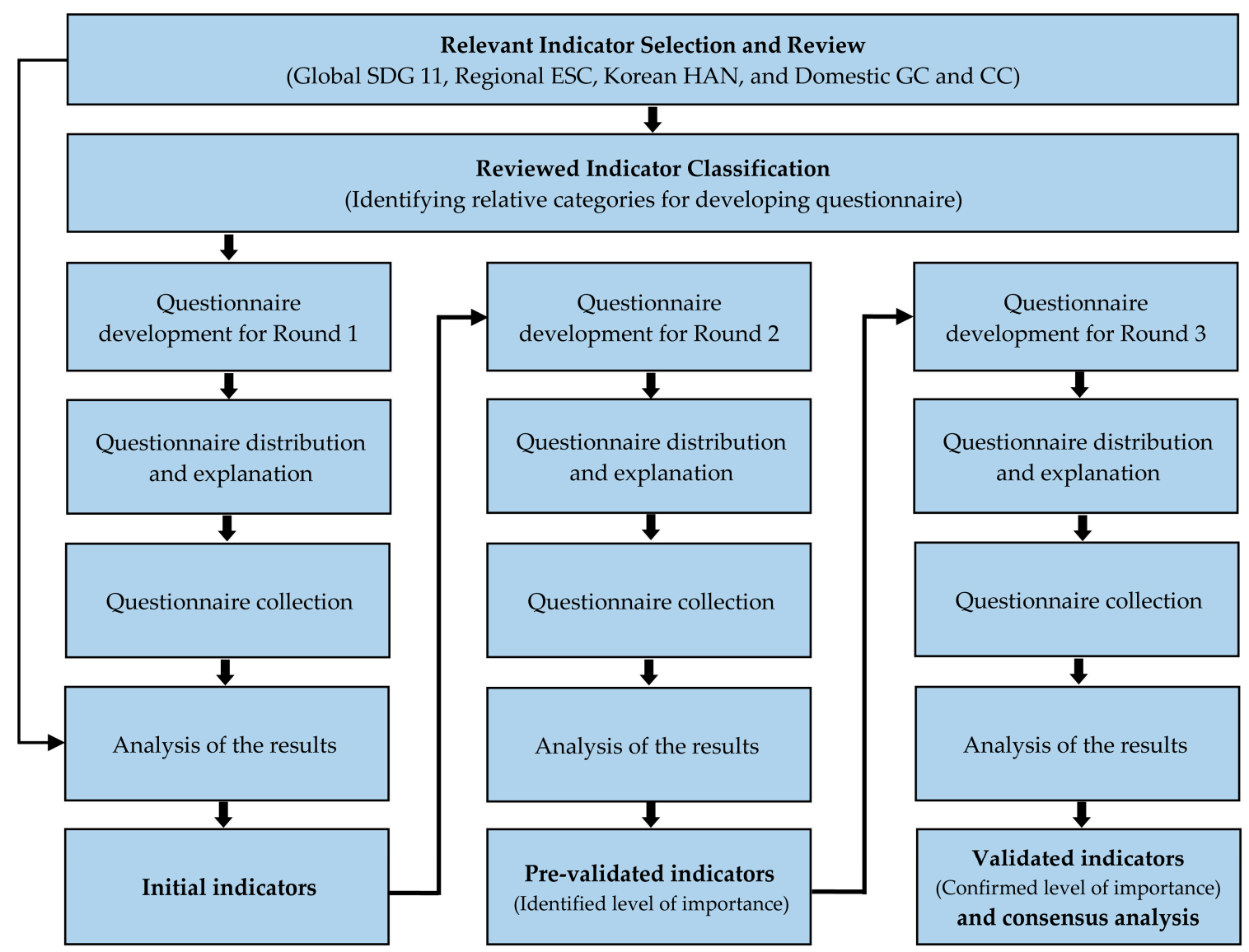

Figure 1. Summary of research flow.

Based on the explanation above, the UN SDG 11 indicators are globally related to Cambodia; the ASEAN ESC indicators are regionally related to Cambodia; and the Korean HAN indicators are potentially related to Cambodia. Furthermore, the green and clean city indicators are domestic available indicators that are related to sustainability. The relations and scopes of these indicators are illustrated in Figure 2.

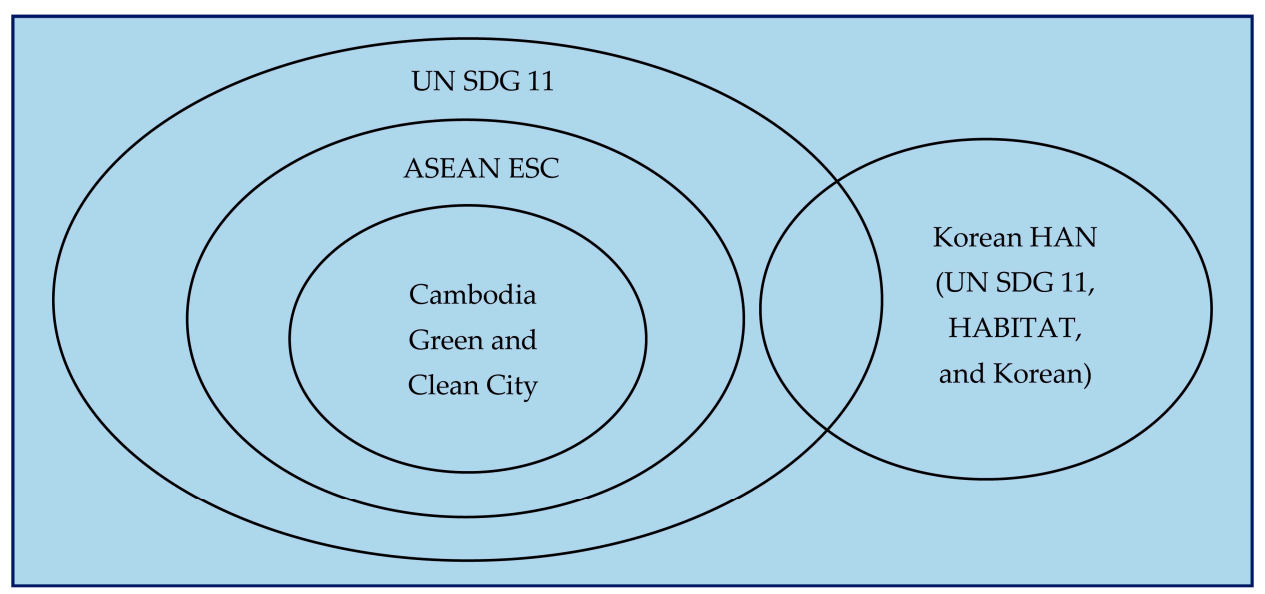

Figure 2. Sources, relations, and scopes of the reviewed indicators. 
Moreover, the reviewed indicators which have parallel descriptions were merged and listed in the same row (see Table 1). These indicators, after classifying by their similarity and correlation, have nine relative categories, such as (1) Demography, (2) Jobs and Tourism, (3) Housing, (4) Transport, (5) Safety, (6) Clean Air and Energy, (7) Waste Management, (8) Water Use, and (9) Public Space and Heritage. These categories are also shown in Table 1 in the column 'Category'.

Table 1. Indicator review and classification.

\begin{tabular}{|c|c|c|c|c|c|c|}
\hline Category & Indicator & SDG11 & ESC & HAN & GC & $\mathrm{CC}$ \\
\hline \multirow{6}{*}{ Demography } & Population density & $\bullet$ & & $\bullet$ & & \\
\hline & Population growth rate & ○ & & $\bullet$ & & \\
\hline & $\begin{array}{l}\text { The ratio of land consumption rate to the population } \\
\text { growth rate }\end{array}$ & $\bullet$ & & $\bullet$ & & \\
\hline & Birth rate & & & $\bullet$ & & \\
\hline & Active population (20-65) rate & & & $\bullet$ & & \\
\hline & Elderly population (over 65 ) rate & & & - & & \\
\hline \multirow{6}{*}{$\begin{array}{l}\text { Jobs and } \\
\text { Tourism }\end{array}$} & Labor force participation rate & & & • & & \\
\hline & Unemployment rate & $\bullet$ & & - & & \\
\hline & $\begin{array}{l}\text { Absence or presence of shopping centers or shopping } \\
\text { outlets within tourist areas }\end{array}$ & & & & & $\bullet$ \\
\hline & $\begin{array}{l}\text { Absence or presence of local products in shopping } \\
\text { centers or shopping outlets within tourist areas }\end{array}$ & & & & & $\bullet$ \\
\hline & Tourism growth rate per year & & & & $\bullet$ & \\
\hline & Number of registered foreigners & & & - & & \\
\hline \multirow{5}{*}{ Housing } & Percentage of the population living in slums & $\bullet$ & & $\bullet$ & & \\
\hline & $\begin{array}{l}\text { Percentage of the population spending more than } 30 \% \\
\text { of their income on housing costs }\end{array}$ & & & $\bullet$ & & \\
\hline & Number of low-income housing units & & & & $\bullet$ & \\
\hline & Percentage of population living in owned houses & & & - & & \\
\hline & Percentage of aging residential buildings & & & $\bullet$ & & \\
\hline \multirow{7}{*}{ Transport } & $\begin{array}{l}\text { Percentage of population living within } 0.5 \mathrm{~km} \text { of } \\
\text { public transport access }\end{array}$ & $\bullet$ & & & & \\
\hline & Percentage of people using large public transports & $\bullet$ & & & & \\
\hline & Public transport sharing rate & & & • & & \\
\hline & Investment in transports under the budget & • & & $\bullet$ & & \\
\hline & Number of taxi and bus & & & $\bullet$ & & \\
\hline & Proportion of environmentally friendly vehicles & & & & & $\bullet$ \\
\hline & $\begin{array}{l}\text { Proportion of traffic congestion level (extra hours of } \\
\text { travel time) }\end{array}$ & & & & $\bullet$ & $\bullet$ \\
\hline \multirow{6}{*}{ Safety } & Absence or presence of measures to prevent crimes & & & $\bullet$ & & $\bullet$ \\
\hline & $\begin{array}{l}\text { Number of people affected by crimes; number of } \\
\text { crimes }\end{array}$ & & & $\bullet$ & & $\bullet$ \\
\hline & Number of affected people resulting from disasters & • & & & & \\
\hline & Number of damaged or destroyed houses & - & & • & & \\
\hline & $\begin{array}{l}\text { Proportion of disaster prevention facilities } \\
\text { (constructed dams, reservoirs, pumping stations etc.) }\end{array}$ & $\bullet$ & & • & $\bullet$ & \\
\hline & Proportion of basic livelihood security & & & $\bullet$ & & \\
\hline
\end{tabular}


Table 1. Cont.

\begin{tabular}{|c|c|c|c|c|c|c|}
\hline Category & Indicator & SDG11 & ESC & HAN & GC & $\mathrm{CC}$ \\
\hline \multirow{13}{*}{$\begin{array}{l}\text { Clean Air } \\
\text { and Energy }\end{array}$} & Fine dust level & $\bullet$ & $\bullet$ & $\bullet$ & & \\
\hline & $\begin{array}{l}\text { Number of days in a year that Pollutant Standards } \\
\text { Index (PSI) exceeded } 100 \text { (unhealthy) using USEPA } \\
\text { standard }\end{array}$ & & $\bullet$ & & & \\
\hline & $\begin{array}{l}\text { Proportion of the city government's efforts in } \\
\text { greenhouse gas reduction }\end{array}$ & & & & $\bullet$ & $\bullet$ \\
\hline & $\begin{array}{l}\text { The ratio of forest conservation areas to the total land } \\
\text { area of the city }\end{array}$ & & & $\bullet$ & & \\
\hline & $\begin{array}{l}\text { Percentage of gasoline- and diesel-fueled vehicles that } \\
\text { meet city or national standards during roadside } \\
\text { inspection }\end{array}$ & & $\bullet$ & & & \\
\hline & $\begin{array}{l}\text { Percentage of industries that fulfill the requirement of } \\
\text { national standards }\end{array}$ & & $\bullet$ & & $\bullet$ & \\
\hline & Types of alternative fuels used & & • & & & \\
\hline & $\begin{array}{l}\text { Percentage of hotels using energy saving devices or } \\
\text { renewable energy }\end{array}$ & & & & & $\bullet$ \\
\hline & $\begin{array}{l}\text { Proportion of awareness campaigns on energy-saving } \\
\text { techniques }\end{array}$ & & & & & $\bullet$ \\
\hline & Proportion of incentives for sustainable use of energy & & & & & • \\
\hline & Percentage of solar energy share in electricity supply & & & & $\bullet$ & \\
\hline & Number of buildings with solar PV installed & & & & $\bullet$ & \\
\hline & Number of green buildings in the city & ○ & & & - & \\
\hline \multirow{7}{*}{$\begin{array}{l}\text { Waste } \\
\text { Management }\end{array}$} & $\begin{array}{l}\text { Percentage of solid waste regularly collected and } \\
\text { recycled }\end{array}$ & • & $\bullet$ & $\bullet$ & $\bullet$ & $\bullet$ \\
\hline & $\begin{array}{l}\text { Percentage of reduction in total waste generated a } \\
\text { year }\end{array}$ & & $\bullet$ & & & \\
\hline & $\begin{array}{l}\text { Percentage of waste collected from door to } \\
\text { door/collection point }\end{array}$ & & $\bullet$ & & & \\
\hline & $\begin{array}{l}\text { Percentage of waste transported in covered vehicles } \\
\text { on a daily basis }\end{array}$ & & $\bullet$ & & & \\
\hline & $\begin{array}{l}\text { Percentage of households and industries linked to } \\
\text { sewerage system }\end{array}$ & & $\bullet$ & & & \\
\hline & $\begin{array}{l}\text { Percentage of households with secured sanitation } \\
\text { systems }\end{array}$ & & & & $\bullet$ & \\
\hline & Proportion of wastewater treatment plants in the city & & & & $\bullet$ & \\
\hline \multirow{5}{*}{ Water Use } & $\begin{array}{l}\text { Percentage of households with tap water that meets } \\
\text { WHO drinking water standard }\end{array}$ & & $\bullet$ & & & \\
\hline & $\begin{array}{l}\text { Percentage of school at all levels with water } \\
\text { conservation education programs }\end{array}$ & & $\bullet$ & & & \\
\hline & $\begin{array}{l}\text { Percentage of capacity of city in supplying water to } \\
\text { meet average consumption }\end{array}$ & & • & & & \\
\hline & $\begin{array}{l}\text { Percentage of available freshwater from ground and } \\
\text { surface water extracted for use }\end{array}$ & & $\bullet$ & & & \\
\hline & $\begin{array}{l}\text { Percentage of households with access to potable } \\
\text { water infrastructure }\end{array}$ & & $\bullet$ & $\bullet$ & & \\
\hline
\end{tabular}


Table 1. Cont.

\begin{tabular}{|c|c|c|c|c|c|c|}
\hline Category & Indicator & SDG11 & ESC & HAN & GC & $\mathrm{CC}$ \\
\hline \multirow{8}{*}{$\begin{array}{l}\text { Public Space } \\
\text { and Heritage }\end{array}$} & $\begin{array}{l}\text { The ratio of public and green spaces compared to the } \\
\text { total area of the city }\end{array}$ & $\bullet$ & $\bullet$ & $\bullet$ & & \\
\hline & $\begin{array}{l}\text { Frequency and time of maintaining and cleaning } \\
\text { public and green spaces }\end{array}$ & & & & & $\bullet$ \\
\hline & $\begin{array}{l}\text { Percentage of the area that complies with the } \\
\text { stipulated spatial plan of the city }\end{array}$ & & $\bullet$ & $\bullet$ & & \\
\hline & Number of urban parks & & & $\bullet$ & & \\
\hline & Proportion of leisure areas in the city & & & & & $\bullet$ \\
\hline & $\begin{array}{l}\text { Percentage of residents residing in public and green } \\
\text { spaces accessible within } 0.5 \mathrm{~km}\end{array}$ & $\bullet$ & & & & \\
\hline & $\begin{array}{l}\text { Percentage of conservative status given to historical } \\
\text { and cultural areas }\end{array}$ & $\bullet$ & & $\bullet$ & & \\
\hline & $\begin{array}{l}\text { Percentage of the budget provided to maintain the } \\
\text { cultural and natural heritage }\end{array}$ & $\bullet$ & & $\bullet$ & & \\
\hline
\end{tabular}

\subsection{Questionnaire Development}

Delphi processes of panel surveys were conducted in three rounds; therefore, the development of questionnaires was not done in one time in this research. Three different questionnaires were developed at different times. The development of questionnaires was as follows:

Round 1: As mentioned in previous sections, the questionnaires for Round 1 were developed based on the relative categories of the reviewed indicators. Generally, sustainable city indicators are various and broad, so it would be difficult and complicated for panelists if they were asked to provide indicators without categories. Therefore, this research developed questionnaires, based on the nine relative categories, into 9-part questions. A sample of a questionnaire in brief for the Demography is shown in Figure 3a. More detail on how it works is explained in Section 2.5.3.

Round 2: Questionnaires for Round 2 were developed based on the initial indicators obtained from Round 1. The purpose of this round was to identify the level of importance of the indicators (preliminarily validate the initially developed indicators). Therefore, this research developed the questionnaires for this round by using a 5-point Likert-type scale. A sample of a questionnaire, in brief, is shown in Figure 3b. More detail on how it works is explained in Section 2.5.3.

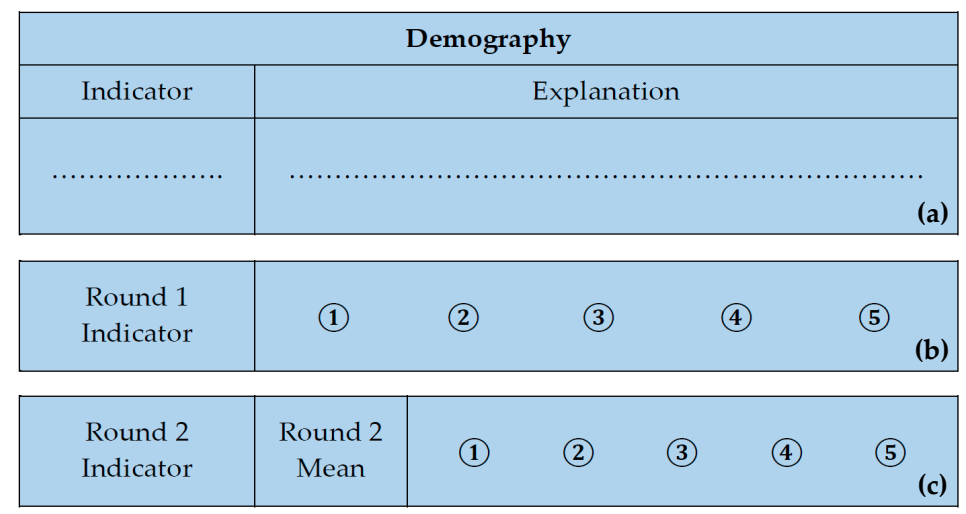

Figure 3. Samples of questionnaires in brief: (a) Delphi Round 1; (b) Delphi Round 2; and (c) Delphi Round 3.

Round 3: Questionnaires for Round 3 were developed based on the pre-validated indicators obtained from Round 2. The purpose of this round was to confirm the level of importance of the 
indicators (to finally validate the indicators). Therefore, questionnaires were developed by adding Round 2 mean values in front of the 5-point Likert-type scale. A sample of a questionnaire in brief for this round is shown in Figure 3c. More detail on how it works is explained in Section 2.5.3.

\subsection{Conducting Panel Surveys}

\subsubsection{Place of Panel Surveys}

With the administrative support from the Ministry of Environment, Department of Green Economy, and General Secretariat of the National Council for Sustainable Development, this research conducted the 3-round Delphi processes of panel surveys at the 'Tung Hall' meeting room of the Ministry of Environment in Phnom Penh capital, the Kingdom of Cambodia.

\subsubsection{Panelist Selection, Invitation, and Participation}

In general, Delphi studies use different sizes of panels [63]. Weidman and colleagues (2011) did not specify the number of panelists needed for a Delphi study; however, it is recognized that a minimum appropriate size should include 7 or 8 panelists [79]. Mitchell and McGoldrick (1994) argued that the size should be no less than 8 to 10 members [38]. Hallowell and Gambatese (2010) mentioned that most studies incorporated 8 to 16 panelists and suggested a minimum of 8 [78]. Following these studies, this research determined that the number of panelists for each round should be no less than 10 . Consequently, this research selected 20 professional panelists whose fields were in and related to urban sustainability, such as sustainable urban and rural development (4), eco-labelling and green buildings (2), green energy and economic policies (3), climate change policy coordination (2), greenhouse gas inventory and reduction strategies (2), administration, planning, and finance (2), ecosystem services (1), biodiversity conservation (1), sustainable consumption and production (1), disaster risk assessment (1), and green technologies (1). All panelists were invited to participate in the panel surveys by the General Secretariat of the National Council for Sustainable Development. A total of 16 of them came to both Round 1 and 2, and 10 of them came to Round 3.

\subsubsection{Panel Survey Processes}

In this research, every panelist was briefed on the research purposes and Delphi processes of panel surveys in the concept note attached with the invitation. Most importantly, these matters were explained again after a set of questionnaires were distributed immediately before starting the survey in Round 1. This explanation was to further focus on how to complete the questionnaires. With the fill-in-blank questions, see Figure 3a, panelists were asked to provide at least 4 sustainable city indicators for Cambodia for each given category. Extra blanks for other categories were also provided in case panelists wanted to add the indicators that were not related to the given categories. Similarly, Sourani and Sohail (2015) asked respondents to provide five major criteria, and respondents were notified that they were welcome to provide more than five criteria [63].

In Round 2, the panelists were instructed how to complete the questionnaires after a set of questionnaires were distributed immediately before starting the survey. As shown in Figure 3b, the questionnaires were developed based on the initial indicators obtained from Round 1 by adding a 5-point Likert-type scale in front of the indicators as follows-1 represents "not important"; 2 represents "less important"; 3 represents "important"; 4 represents "very important"; and 5 represents "extremely important" $[63,76]$. The panelists were asked to assess the level of importance of the initial indicators.

In Round 3, the panelists were also told about how to complete the questionnaires after distribution immediately before starting the survey. As shown in Figure $3 c$, the questionnaires were developed based on the pre-validated indicators obtained from Round 2 by adding Round 2 mean value and 5-point Likert-type scale in front of the indicators. The purpose of this round was to re-check the level of importance of the pre-validated indicators because the individual panelists could change 
their opinions and judgements based on the Round 2 mean value. Likewise, Gene and George (1999) argued that with the iteration, the individuals are given the opportunity to change their opinions and judgments [57]. Therefore, the panelists in this round were asked to re-assess the level of importance of the pre-validated indicators based on the statistical mean value obtained from Round 2.

\subsection{Analyzing Consensus and Investigation}

In this research, the consensus was not analyzed in Round 2 because, as explained in the previous sections, the level of importance of the indicators in Round 2 was not yet definitely confirmed; however, the Round 2 mean value helped panelists to make final decision to confirm the level of importance of the indicators in Round 3. Therefore, this research analyzed the consensus in Round 3. According to Hughes (2003) [84], the consensus is to determine the extent to which panelists agree about a given issue. Quite commonly, it is defined by more than $83 \%$ of the responses voting for the issue as "important or very important or extremely important". Sourani and Sohail (2015) [63] proposed that the developed consensus is based on identifying and assigning, for each criterion, the mean value, standard deviation, and percentage of respondents agreeing on ranking the criterion. On a 5-point Likert-type scale, the consensus can be established based on reaching $75 \%$ or above of the respondents agreeing on a given rank that is equal to or above 3.00. Therefore, this research accordingly determined the consensus based on the confirmed level of importance of the indicators at equal to or above 3.00, and the percentage of panelists agreeing on a given rank from 3 to 5 at equal to or above $75 \%$. The validated indicators that reached this consensus were chosen as sustainable city indicators (SCIs) for Cambodia.

Furthermore, the consensus sustainable city indicators are, based on the validations and agreements, suitable for Cambodia's urban context for the development of sustainable cities. Therefore, this research sought to address the questions "Are the green and clean city indicators limited in terms of sustainability?" and "Are the UN SDG 11 indicators suitable for Cambodia?" based on the consensus indicators. In addition, how the green and clean city and UN SDG 11 indicators are limited or suitable for Cambodia in terms of sustainability was also investigated through the correlation of these indicators with the consensus indicators.

\section{Results}

\subsection{Indicator Development in Delphi Round 1}

After analyzing the results of Delphi Round 1, this research obtained the categories and initial indicators as follows. The number of categories remained the same as the number of the reviewed indicators (9 categories), but three categories underwent a name change. The 'jobs and tourism' and 'public space and heritage' were changed to 'employment' and 'urban space and tourism'. The 'clean air and energy' was changed to 'noise, air quality, and energy' (see Table 2). These changes were based on the obtained initial indicators and comments and suggestions from the panelists. 
Table 2. The obtained categories and initial indicators.

\begin{tabular}{|c|c|c|}
\hline Category & & Indicator \\
\hline \multirow{8}{*}{ Demography } & SCI1 & Population density \\
\hline & SCI2 & Population growth rate \\
\hline & $\mathrm{SCI} 3$ & Average of household income \\
\hline & SCI4 & Birth rate \\
\hline & SCI5 & Percentage of the population aged 65 and over \\
\hline & SCI6 & Percentage of the population migrating into the city \\
\hline & SCI7 & Percentage of the population with disabilities \\
\hline & SCI8 & Mortality rate \\
\hline \multirow{7}{*}{ Employment } & SCI9 & Labor force participation rate \\
\hline & SCI10 & Unemployment rate \\
\hline & SCI11 & Percentage of the foreign companies investing in the city \\
\hline & SCI12 & Number of new jobs created per year \\
\hline & SCI13 & Percentage of the shopping center or outlets selling local products \\
\hline & SCI14 & Employment participation rate by age and gender \\
\hline & SCI15 & Absence or presence of SMEs competition \\
\hline \multirow{7}{*}{ Housing } & SCI16 & Number of low-income housing development projects \\
\hline & SCI17 & Percentage of the population living in slums \\
\hline & SCI18 & Percentage of new residential buildings (aged less than 30 years) \\
\hline & SCI19 & Percentage of the population living in owned houses \\
\hline & SCI20 & Percentage of the population living in rent houses \\
\hline & SCI21 & Percentage of aging residential buildings (aged more than 30 years) \\
\hline & SCI22 & The radio of middle-income houses compared to the low-income houses \\
\hline \multirow{8}{*}{ Transport } & SCI23 & Public transport sharing rate \\
\hline & SCI24 & Number of initiatives to reduce traffic congestion \\
\hline & SCI25 & Number of initiatives for sidewalk improvement \\
\hline & SCI26 & Number of public parking lots in the city \\
\hline & SCI27 & Percentage of the population living within $0.5 \mathrm{~km}$ of public transport access \\
\hline & SCI28 & Percentage of environmentally friendly vehicles \\
\hline & SCI29 & Number of road cleaning times per week or per month \\
\hline & SCI30 & Proportion of streets with lights \\
\hline \multirow{7}{*}{ Safety } & SCI31 & Number of measures or initiatives to prevent crimes \\
\hline & SCI32 & Number of facilities to prevent disasters \\
\hline & SCI33 & $\begin{array}{l}\text { Number of initiated programs to protect workers or road users from construction } \\
\text { risks }\end{array}$ \\
\hline & SCI34 & Percentage of residents using insurance services; number of insurance companies \\
\hline & SCI35 & Number of damaged or destroyed houses \\
\hline & SCI36 & Number of people affected by crimes; number of crimes \\
\hline & SCI37 & Number of affected people resulting from disasters \\
\hline \multirow{7}{*}{ Water Use } & SCI38 & Percentage of households with access to potable water infrastructure \\
\hline & SCI39 & Percentage of households with tap water that meets WHO drinking water standard \\
\hline & SCI40 & Number of natural or artificial reservoirs in or nearby the city \\
\hline & SCI41 & Average of the water consumption rate per person or household \\
\hline & SCI42 & Percentage of water use in production \\
\hline & SCI43 & The ratio of water use from underground and surface water \\
\hline & SCI44 & Percentage of school at all levels with water conservation education programs \\
\hline
\end{tabular}


Table 2. Cont.

\begin{tabular}{|c|c|c|}
\hline Category & & Indicator \\
\hline \multirow{8}{*}{$\begin{array}{c}\text { Waste } \\
\text { Management }\end{array}$} & SCI45 & Percentage of solid waste regularly collected \\
\hline & SCI46 & The capacity of wastewater treatment plants in the city \\
\hline & SCI47 & Percentage of households linked to the sewerage system \\
\hline & SCI48 & Number of initiatives to reduce wastes \\
\hline & SCI49 & Percentage of reduction in total waste generated per year \\
\hline & SCI50 & Percentage of recycled waste from total waste generation \\
\hline & SCI51 & Number of households with secured sanitation systems \\
\hline & SCI52 & Percentage of waste collected from door to door or collection point \\
\hline \multirow{8}{*}{$\begin{array}{c}\text { Noise, Air } \\
\text { Quality and } \\
\text { Energy }\end{array}$} & SCI53 & Average of the energy consumption rate per person or household \\
\hline & SCI54 & Percentage of the urban forest \\
\hline & SCI55 & Fine dust levels \\
\hline & SCI56 & Number of measures or initiatives to control noise in the city \\
\hline & SCI57 & Absence or presence of greenhouse gas reduction strategies \\
\hline & SCI58 & Percentage of renewable energy contributed to the electricity supply \\
\hline & SCI59 & Percentage of hotels using energy saving devices \\
\hline & SCI60 & Percentage of green buildings in the city \\
\hline \multirow{9}{*}{$\begin{array}{l}\text { Urban } \\
\text { Space and } \\
\text { Tourism }\end{array}$} & SCI61 & The ratio of public and green spaces compared to the total area of the city \\
\hline & SCI62 & Number of natural or artificial parks in the city \\
\hline & SCI63 & Percentage of residents living within $0.5 \mathrm{~km}$ of public and green space access \\
\hline & SCI64 & Tourism growth rate per year \\
\hline & SCI65 & Number of conserved cultural, historical, and heritage buildings \\
\hline & SCI66 & Number of tourism firms providing tourism services in the city \\
\hline & SCI67 & Number of botanic gardens in the city \\
\hline & SCI68 & Number of playgrounds in the city \\
\hline & SCI69 & Number of zoological gardens in the city \\
\hline
\end{tabular}

Furthermore, the maximum number of the initial indicators is 9 and the minimum number of the initial indicators is 7. Number of indicators obtained in each category are 8 in 'demography', 7 in 'employment', 7 in 'housing', 8 in 'transport', 7 in 'safety', 7 in 'water use', 8 in 'waste management', 8 in 'noise, air quality and energy', and 9 in 'urban space and tourism' (see Figure 4).

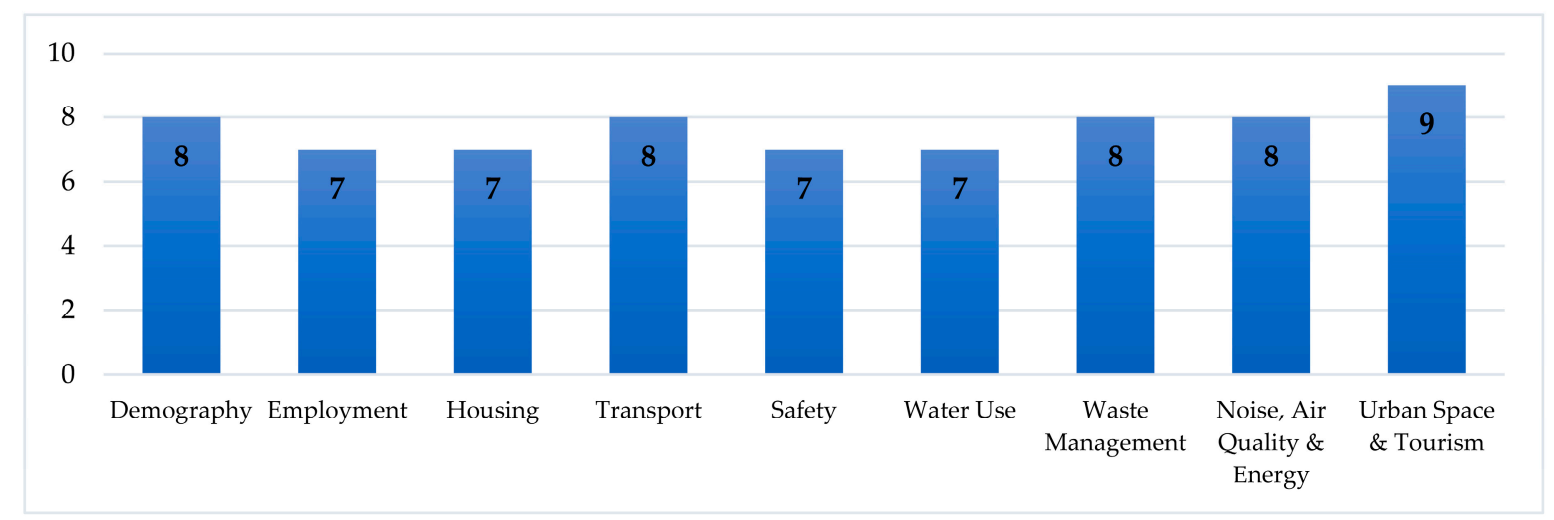

Figure 4. Number of initial indicators obtained in each category.

The highest frequency is 100\% (16/16) and the lowest frequency is $6 \%(1 / 16)$. The highest-frequency indicators are SCI1 in 'demography', SCI23 in 'transport', SCI31 in 'safety' and SCI45 in 'waste management'. The top indicator in each category are SCI1 in 'demography', SCI9 in 'employment', SCI16 in 'housing', SCI23 in 'transport', SCI31 in 'safety', SCI38 in 'water use', SCI45 in 'waste management', SCI53 and SCI54 in 'noise, air quality and energy', and SCI61 in 'urban space and tourism' (see Figure 5). 


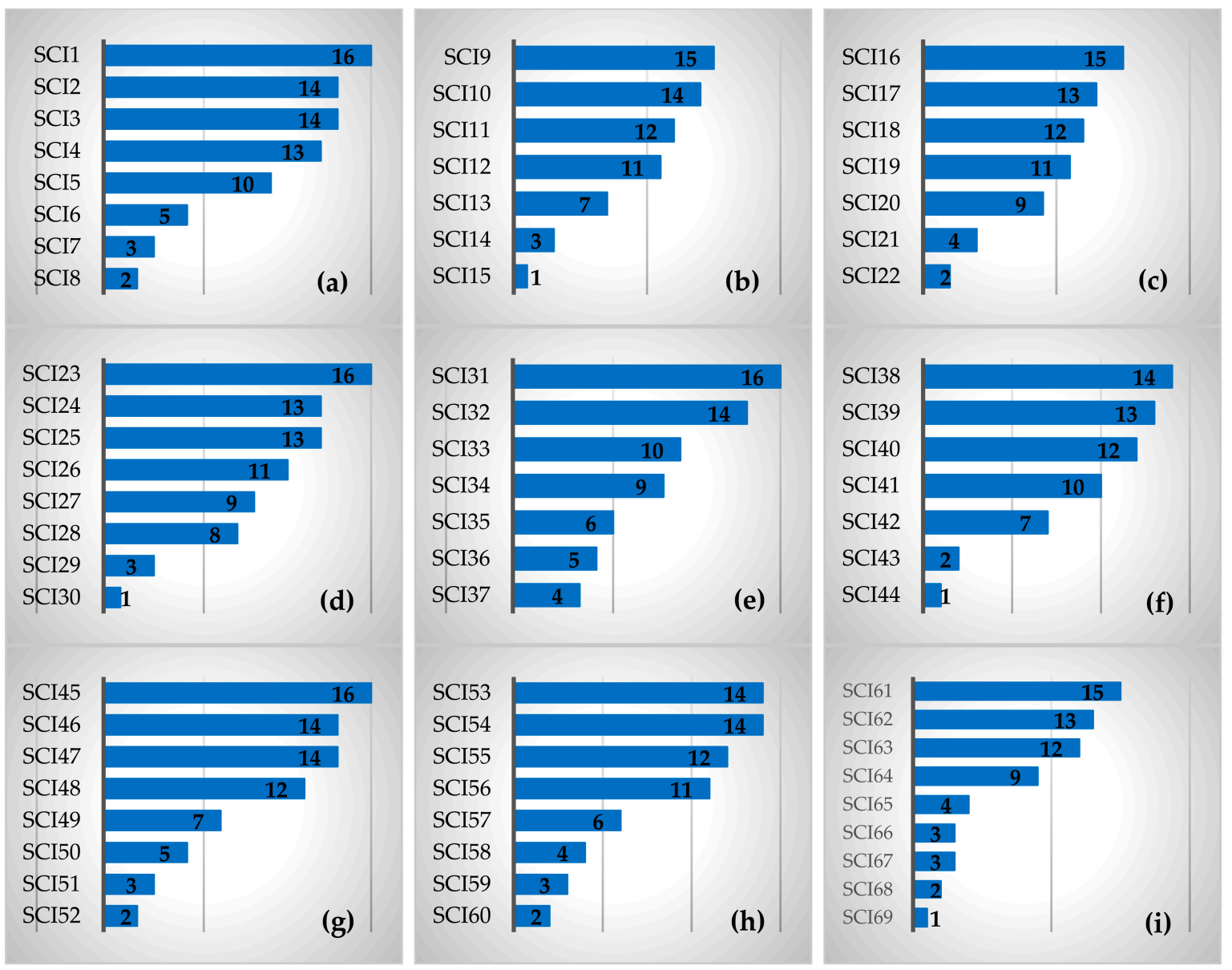

Figure 5. Frequency of initial indicators in Round 1: (a) Demography; (b) employment; (c) housing; (d) transport; (e) safety; (f) water use; (g) waste management; (h) noise, air quality and energy; and (i) urban space and tourism.

\subsection{Indicator Pre-Validation in Delphi Round 2}

After analyzing the results of Delphi Round 2, this research obtained the pre-validated indicators as follows. The maximum number of indicators is 6 and the minimum number of indicators is 3 . Number of the indicators obtained in each category are 4 in 'demography', 5 in 'employment', 3 in 'housing', 5 in 'transport', 4 in 'safety', 5 in 'water use', 4 in 'waste management', 5 in 'noise, air quality and energy', and 6 in 'urban space and tourism' (see Figure 6).

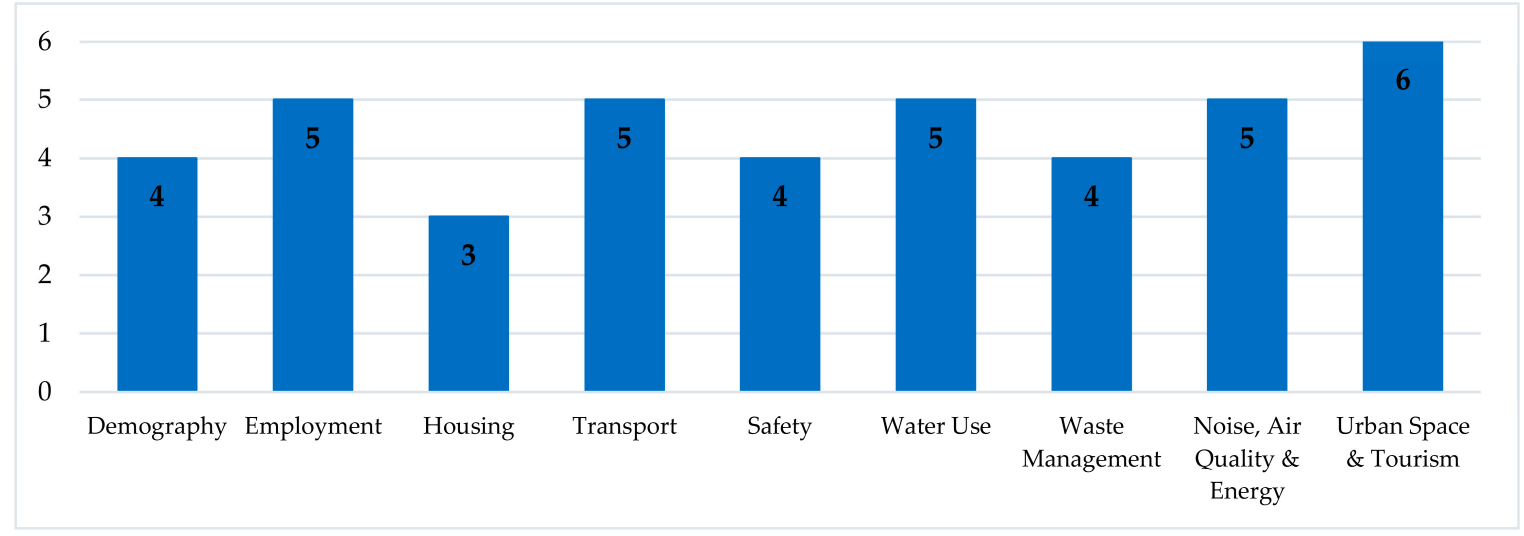

Figure 6. Number of the pre-validated indicators obtained in each category. 
The maximum mean value is 4.63 and the minimum mean value is 3.00 . The maximum-mean-value indicator is SCI38 in 'water use'. The top indicator (maximum-mean-value indicator) in each category are SCI1 in 'demography', SCI12 in 'employment', SCI6 in 'housing', SCI25 in 'transport', SCI31 and SCI33 in 'safety', SCI38 in 'water use', SCI46 in 'waste management', SCI54 in 'noise, air quality and energy', and SCI62 in 'urban space and tourism' (see Figure 7).
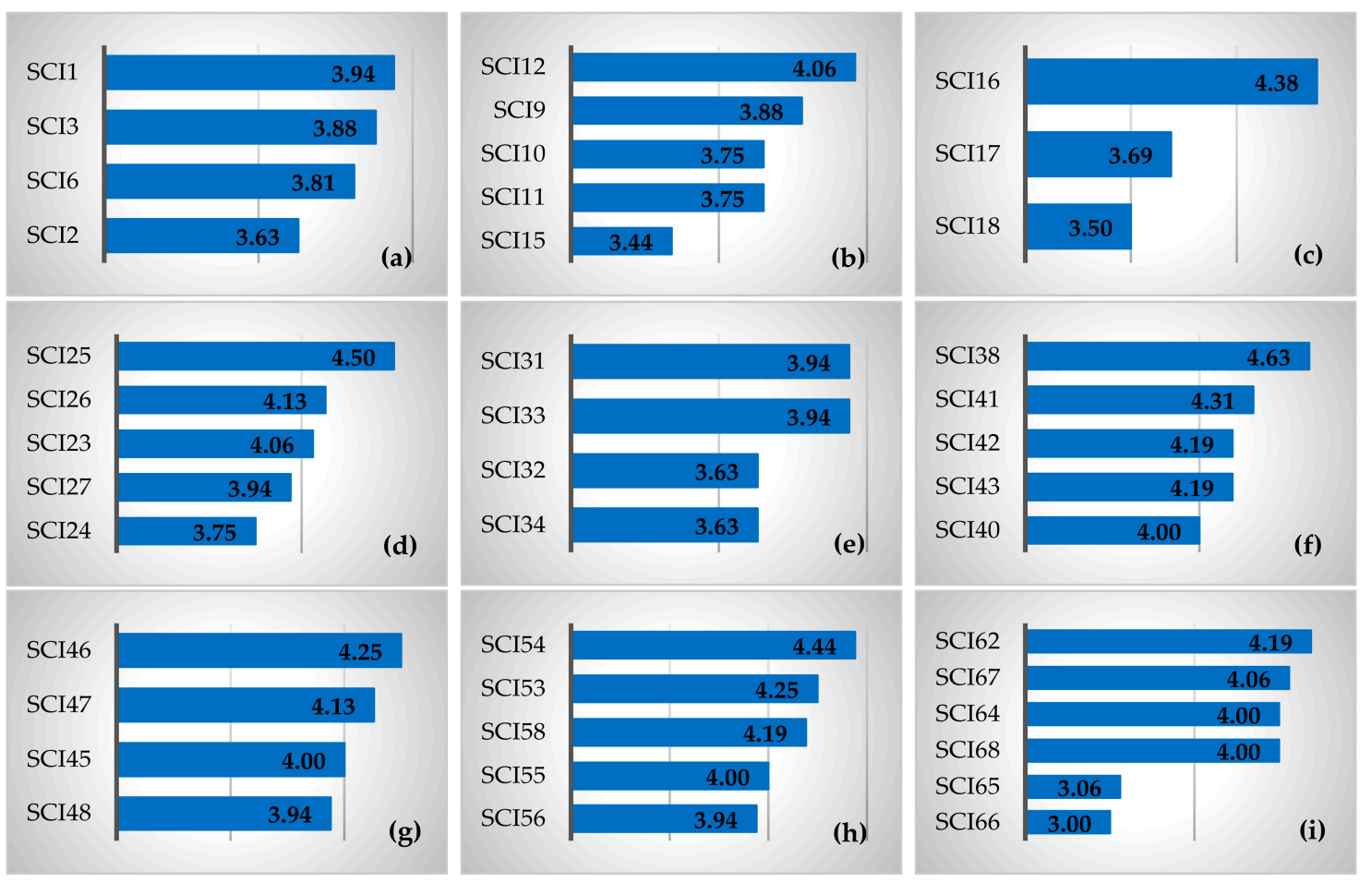

Figure 7. Mean value of the pre-validated indicators: (a) Demography; (b) employment; (c) housing; (d) transport; (e) safety; (f) water use; (g) waste management; (h) noise, air quality and energy; and (i) urban space and tourism.

\subsection{Indicator Validation in Delphi Round 3}

After analyzing the results of Delphi Round 3, this research obtained the categories and validated indicators as follows. One category named 'noise, air quality, and energy' was changed to 'air quality and energy' because noise indicator in this category obtained mean value (level of importance) lower than 3.00 after final validation. The maximum number of indicators is 5 and the minimum number of indicators is 3 . Number of the indicators obtained in each category are 3 in 'demography', 3 in 'employment', 3 in 'housing', 4 in 'transport', 4 in 'safety', 3 in 'water use', 3 in 'waste management', 4 in 'air quality and energy', and 5 in 'urban space and tourism' (see Figure 8).

The maximum mean value is 4.80 and the minimum mean value is 3.50 . The maximum-mean-value indicator is SCI25 in 'transport'. The top indicator (maximum-mean-value indicator) in each category are SCI3 in 'demography', SCI12 in 'employment', SCI16 in 'housing', SCI25 in 'transport', SCI31 in 'safety', SCI38 in 'water use', SCI45 in 'waste management', SCI55 in 'air quality and energy', and SCI67 and SCI62 in 'urban space and tourism' (see Figure 9). 


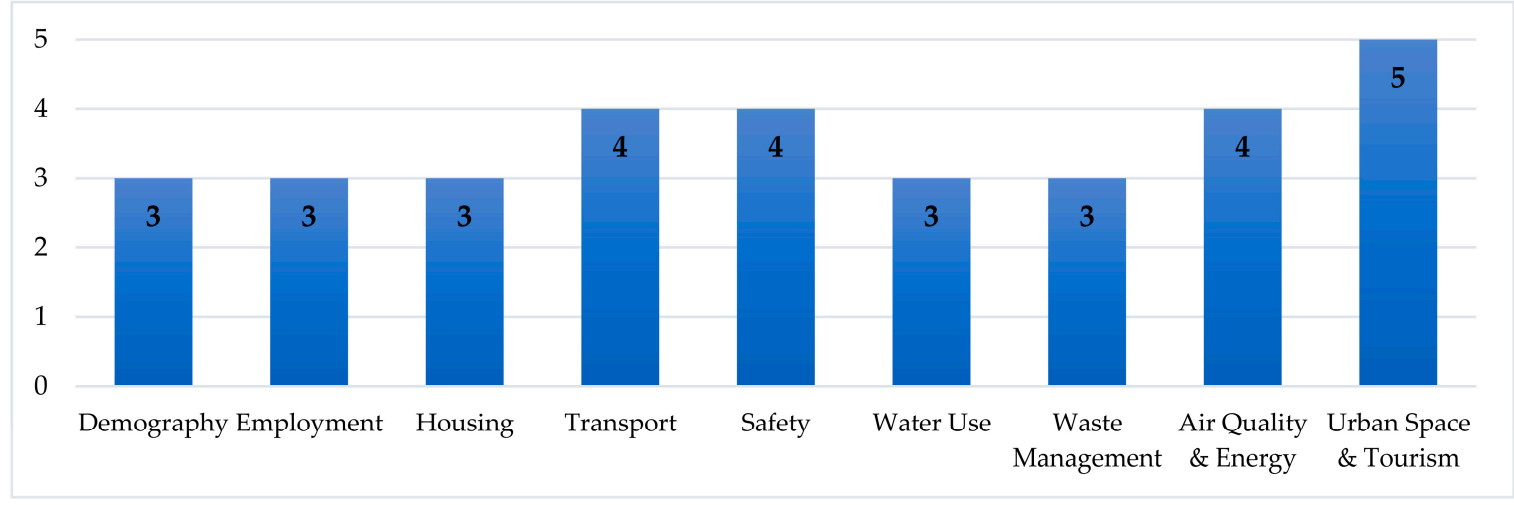

Figure 8. Number of the validated indicators obtained in each category.

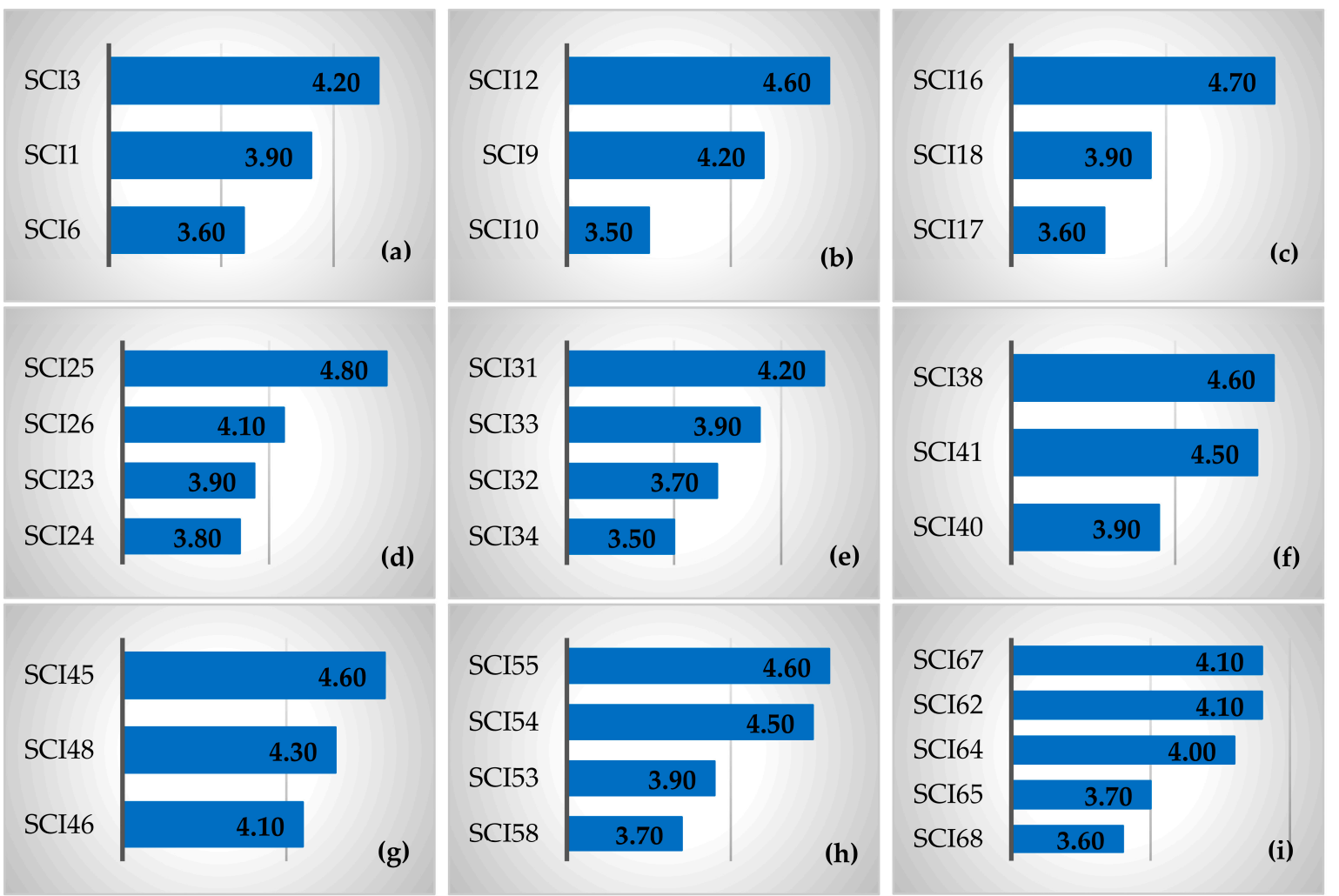

Figure 9. Mean value of the validated indicators: (a) Demography; (b) employment; (c) housing; (d) transport; (e) safety; (f) water use; (g) waste management; (h) air quality and energy; and (i) urban space and tourism.

\subsection{Consensus Analysis}

Based on the determined consensus, the developed indicators need to be confirmed with regard to the level of importance at equal to or above 3.00 and percentage voting as 5 or 4 or 3 at equal to or above $75 \%$. According to the consensus analysis, percentage of panelists voting as 5 or 4 or 3 for the 32 validated indicators is $100 \%$ for 28 indicators and $90 \%$ for 4 indicators. Therefore, all of the 32 indicators reached consensus (see Table 3). 
Table 3. Consensus analysis.

\begin{tabular}{|c|c|c|c|c|c|c|c|c|c|c|}
\hline \multirow{2}{*}{ Category } & \multirow{2}{*}{ Indicator } & \multirow{2}{*}{ Mean } & \multirow{2}{*}{ SD } & \multicolumn{7}{|c|}{ Percentage of Panelists Voting for Indicator as } \\
\hline & & & & 5 & 4 & 3 & 2 & 1 & $\begin{array}{c}5 \text { or } 4 \\
\text { or } 3\end{array}$ & $\begin{array}{c}2 \text { or } \\
1\end{array}$ \\
\hline \multirow{3}{*}{ Demography } & SCI3 & 4.20 & 0.60 & 30.00 & 60.00 & 10.00 & 0 & 0 & 100.00 & 0 \\
\hline & SCI1 & 3.90 & 0.83 & 30.00 & 30.00 & 40.00 & 0 & 0 & 100.00 & 0 \\
\hline & SCI6 & 3.60 & 0.92 & 20.00 & 30.00 & 40.00 & 10.00 & 0 & 90.00 & 10.00 \\
\hline \multirow{3}{*}{ Employment } & SCI12 & 4.60 & 0.49 & 60.00 & 40.00 & 0 & 0 & 0 & 100.00 & 0 \\
\hline & SCI9 & 4.20 & 0.75 & 40.00 & 40.00 & 20.00 & 0 & 0 & 100.00 & 0 \\
\hline & SCI10 & 3.50 & 1.02 & 10.00 & 40.00 & 40.00 & 10.00 & 0 & 90.00 & 10.00 \\
\hline \multirow{3}{*}{ Housing } & SCI16 & 4.70 & 0.46 & 70.00 & 30.00 & 0 & 0 & 0 & 100.00 & 0 \\
\hline & SCI18 & 3.90 & 0.94 & 30.00 & 40.00 & 20.00 & 10.00 & 0 & 90.00 & 10.00 \\
\hline & SCI17 & 3.60 & 0.66 & 10.00 & 40.00 & 50.00 & 0 & 0 & 100.00 & 0 \\
\hline \multirow{4}{*}{ Transport } & SCI25 & 4.80 & 0.40 & 80.00 & 20.00 & 0 & 0 & 0 & 100.00 & 0 \\
\hline & SCI26 & 4.10 & 0.83 & 40.00 & 30.00 & 30.00 & 0 & 0 & 100.00 & 0 \\
\hline & SCI23 & 3.90 & 1.04 & 40.00 & 20.00 & 30.00 & 10.00 & 0 & 90.00 & 10.00 \\
\hline & SCI24 & 3.80 & 0.60 & 10.00 & 60.00 & 30.00 & 0 & 0 & 100.00 & 0 \\
\hline \multirow{4}{*}{ Safety } & SCI31 & 4.20 & 0.75 & 40.00 & 40.00 & 20.00 & 0 & 0 & 100.00 & 0 \\
\hline & SCI33 & 3.90 & 0.70 & 20.00 & 50.00 & 30.00 & 0 & 0 & 100.00 & 0 \\
\hline & SCI32 & 3.70 & 0.64 & 10.00 & 50.00 & 40.00 & 0 & 0 & 100.00 & 0 \\
\hline & SCI34 & 3.50 & 0.67 & 10.00 & 30.00 & 60.00 & 0 & 0 & 100.00 & 0 \\
\hline \multirow{3}{*}{ Water Use } & SCI38 & 4.60 & 0.49 & 60.00 & 40.00 & 0 & 0 & 0 & 100.00 & 0 \\
\hline & SCI41 & 4.50 & 0.67 & 60.00 & 30.00 & 10.00 & 0 & 0 & 100.00 & 0 \\
\hline & SCI40 & 3.90 & 0.70 & 20.00 & 50.00 & 30.00 & 0 & 0 & 100.00 & 0 \\
\hline \multirow{3}{*}{$\begin{array}{c}\text { Waste } \\
\text { Management }\end{array}$} & SCI45 & 4.60 & 0.66 & 70.00 & 20.00 & 10.00 & 0 & 0 & 100.00 & 0 \\
\hline & SCI48 & 4.30 & 0.78 & 50.00 & 30.00 & 20.00 & 0 & 0 & 100.00 & 0 \\
\hline & SCI46 & 4.10 & 0.83 & 40.00 & 30.00 & 30.00 & 0 & 0 & 100.00 & 0 \\
\hline \multirow{4}{*}{$\begin{array}{l}\text { Air Quality } \\
\text { and Energy }\end{array}$} & SCI55 & 4.60 & 0.49 & 60.00 & 40.00 & 0 & 0 & 0 & 100.00 & 0 \\
\hline & SCI54 & 4.50 & 0.67 & 60.00 & 30.00 & 10.00 & 0 & 0 & 100.00 & 0 \\
\hline & SCI53 & 3.90 & 0.70 & 20.00 & 50.00 & 30.00 & 0 & 0 & 100.00 & 0 \\
\hline & SCI58 & 3.70 & 0.64 & 10.00 & 50.00 & 40.00 & 0 & 0 & 100.00 & 0 \\
\hline \multirow{5}{*}{$\begin{array}{l}\text { Urban Space } \\
\text { and Tourism }\end{array}$} & SCI67 & 4.10 & 0.70 & 30.00 & 50.00 & 20.00 & 0 & 0 & 100.00 & 0 \\
\hline & SCI62 & 4.10 & 0.83 & 40.00 & 30.00 & 30.00 & 0 & 0 & 100.00 & 0 \\
\hline & SCI64 & 4.00 & 0.77 & 30.00 & 40.00 & 30.00 & 0 & 0 & 100.00 & 0 \\
\hline & SCI65 & 3.70 & 0.90 & 30.00 & 10.00 & 60.00 & 0 & 0 & 100.00 & 0 \\
\hline & SCI68 & 3.60 & 0.80 & 20.00 & 20.00 & 60.00 & 0 & 0 & 100.00 & 0 \\
\hline
\end{tabular}

\subsection{Development, Validation, and Consensus}

This research conducted the Delphi processes of panel surveys to develop and validate sustainable city indicators for Cambodia. Through the development process, 69 indicators were initially developed. Through validation processes, the 69 initial indicators were reduced to 41 indicators after identifying the level of importance (pre-validation). Furthermore, the 41 pre-validated indicators were further reduced to 32 indicators after confirming the level of importance (validation). All of the 32 validated indicators reached consensus (Figure 10). 


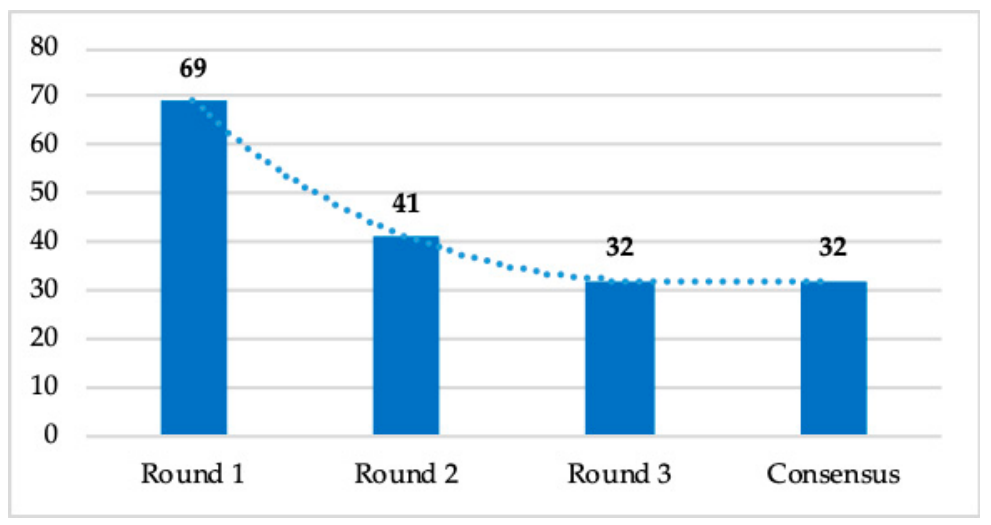

Figure 10. Number of indicators decreased before reaching consensus.

The number of indicators in each category decreased from one round to the next round until reaching the consensus. The number of indicators decreased from 8 to 3 in 'demography', 7 to 3 in 'employment' and 'housing', 8 to 4 in 'transport', 7 to 4 in 'safety', 7 to 3 in 'water use', 8 to 3 in 'waste management', 8 to 4 in 'air quality and energy', and 9 to 5 in 'urban space and tourism' (Figure 11). Furthermore, the top indicator in each category has also changed the rank from Round 1 to Round 3. There are only three top indicators have not changed their rank, since Round 1 until reaching the consensus. These top indicators are SCI16 in 'housing', SCI31 in 'Safety', and SCI38 in 'water use'. Moreover, how all indicators have changed their ranks is also shown in Table A2 (Appendix B).

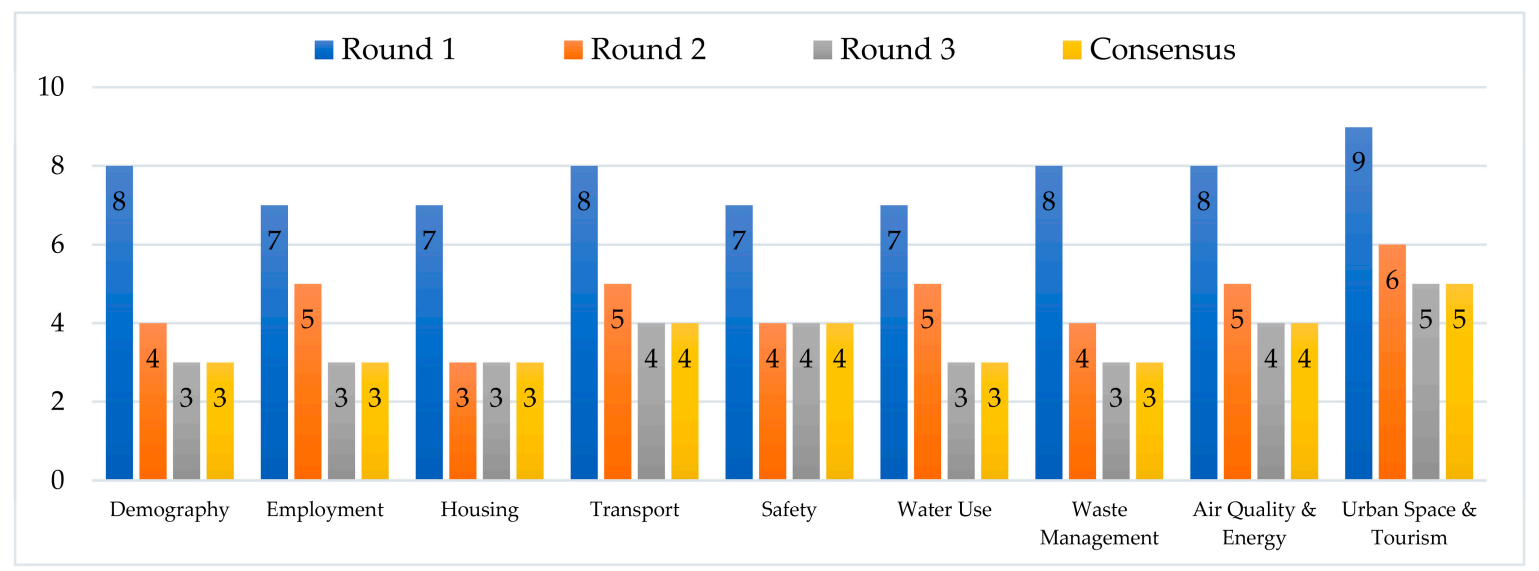

Figure 11. Number of indicators decreased from one round to the next round in each category.

\subsection{Correlation of Green and Clean City, UN SDG 11, and Consensus Indicators}

According to Table 4, the green and clean city indicators correlate with 11 consensus indicators. However, these indicators have no correlation in 'demography', 'employment', and 'water use' and only one for each in 'housing' and 'air quality and energy'. Furthermore, the UN sustainable development goal 11 indicators correlate with nine consensus indicators. This number is less than the number of green and clean city indicators correlated with the consensus indicators. However, these indicators correlate with all categories of the consensus indicators (one indicator for each category). The consensus indicators and their short explanations are shown in Table A3. 
Table 4. Correlation of the green and clean city and UN SDG 11 indicators with the consensus indicators.

\begin{tabular}{|c|c|c|c|}
\hline Category & Consensus & GC and CC & SDG 11 \\
\hline \multirow{3}{*}{ Demography } & SCI3: Average of household income & & \\
\hline & SCI1: Population density & & $\bullet$ \\
\hline & SCI6: Percentage of the population migrating into the city & & \\
\hline \multirow{3}{*}{ Employment } & SCI12: Number of new jobs created per year & & \\
\hline & SCI9: Labor force participation rate & & \\
\hline & SCI10: Unemployment rate & & ? \\
\hline \multirow{3}{*}{ Housing } & SCI16: Number of low-income housing development projects & $\bullet$ & \\
\hline & $\begin{array}{l}\text { SCI18: Percentage of new residential buildings (aged less than } \\
30 \text { years) }\end{array}$ & & \\
\hline & SCI17: Percentage of the population living in slums & & $\bullet$ \\
\hline \multirow{4}{*}{ Transport } & SCI25: Number of initiatives for sidewalk improvement & & \\
\hline & SCI26: Number of public parking lots in the city & & \\
\hline & SCI23: Public transport sharing rate & • & • \\
\hline & SCI24: Number of initiatives to reduce traffic congestion & • & \\
\hline \multirow{4}{*}{ Safety } & SCI31: Number of measures or initiatives to prevent crimes & • & \\
\hline & $\begin{array}{l}\text { SCI33: Number of initiated programs to protect workers or road } \\
\text { users from construction risks }\end{array}$ & & \\
\hline & SCI32: Number of facilities to prevent disasters & • & $\bullet$ \\
\hline & $\begin{array}{l}\text { SCI34: Percentage of residents using insurance services; number } \\
\text { of insurance companies }\end{array}$ & & \\
\hline \multirow{3}{*}{ Water Use } & $\begin{array}{l}\text { SCI38: Percentage of households with access to potable water } \\
\text { infrastructure }\end{array}$ & & $\bullet$ \\
\hline & $\begin{array}{l}\text { SCI41: Average of the water consumption rate per person or } \\
\text { household }\end{array}$ & & \\
\hline & $\begin{array}{l}\text { SCI40: Number of natural or artificial reservoirs in or nearby the } \\
\text { city }\end{array}$ & & \\
\hline \multirow{3}{*}{$\begin{array}{l}\text { Waste } \\
\text { Management }\end{array}$} & SCI45: Percentage of solid waste regularly collected & $\bullet$ & $\bullet$ \\
\hline & SCI48: Number of initiatives to reduce wastes & $\bullet$ & \\
\hline & SCI46: Capacity of wastewater treatment plants in the city & • & \\
\hline \multirow{4}{*}{$\begin{array}{l}\text { Air Quality } \\
\text { and Energy }\end{array}$} & SCI55: Fine dust levels & & • \\
\hline & SCI54: Percentage of the urban forest & & \\
\hline & $\begin{array}{l}\text { SCI53: Average of the energy consumption rate per person or } \\
\text { household }\end{array}$ & & \\
\hline & $\begin{array}{l}\text { SCI58: Percentage of renewable energy contributed to the } \\
\text { electricity supply }\end{array}$ & $\bullet$ & \\
\hline \multirow{5}{*}{$\begin{array}{l}\text { Urban Space } \\
\text { and Tourism }\end{array}$} & SCI62: Number of natural or artificial parks in the city & & \\
\hline & SCI67: Number of botanic gardens in the city & & \\
\hline & SCI64: Tourism growth rate per year & $\bullet$ & \\
\hline & $\begin{array}{l}\text { SCI65: Number of conserved cultural, historical, and heritage } \\
\text { buildings }\end{array}$ & $\bullet$ & $\bullet$ \\
\hline & SCI68: Number of playgrounds in the city & & \\
\hline
\end{tabular}




\section{Discussion}

This research started from the review of five major source indicators, such as UN Sustainable Development Goal 11, ASEAN Environmentally Sustainable City, Korean HAN, and domestic green and clean city indicators. These reviewed indicators were classified based on their similarity and correlation in order to identify relative categories for developing questionnaires for Delphi Round 1. These indicators were also used to supplement the measurement-lacked indicators obtained from Delphi Round 1. Even though the indicator development was initially started by these processes, the obtained 69 initial indicators are various compared to the reviewed indicators. This shows that the reviewed indicators are not inclusively suitable for the development and management of sustainable cities in Cambodia based on the panelists' opinions. Furthermore, the 69 initial indicators were reduced to 41 indicators through the pre-validation process in Round 2. This shows that 28 of the initial indicators were assessed by the panelists as 'not or less important' in Round 2. Moreover, the 41 indicators were further reduced to 32 indicators through the final validation process in Round 3. This shows that nine of the pre-validated indicators were re-assessed by the panelists as 'not or less important' in Round 3 even though these indicators were assessed as 'important' in Round 2. In this case, perhaps individual panelist firstly thought that the indicators they provided in Round 1 were important, but after seeing all initial indicators, they changed their opinions and judgments accordingly. Likewise, after seeing the mean value (level of importance of the pre-validated indicators) obtained from Round 2, individual panelist made the final decision to further reduce the not-or-less-important indicators. However, all of the 32 validated indicators reached consensus. Especially, the confirmed levels of importance and consensus rates of the indicators are strong and high. The levels of importance are all equal to or above 3.50 and the consensus rates are all equal to or above $90.00 \%$. The 32 consensus indicators could, therefore, be significant for the measurement of sustainable city development in Cambodia.

The green and clean city indicators have no correlation with the consensus indicators in 'demography', 'employment', and 'water use' and only one for each in 'housing' and 'air quality and energy'. This shows that current green and clean city indicators are limited in terms of sustainability. Especially, these indicators are very limited in terms of 'housing, air quality, and energy' indicators. Most importantly, these indicators are extremely limited in terms of 'demography, employment, and water use' indicators. These findings could be useful for making decisions on the improvement of the green and clean city indicators and transformation of these indicators to sustainable city indicators. Based on the correlation with consensus indicators, transforming these indicators to sustainable city indicators should be made as follows: (a) Indicators for demography need to be comprised of household income, population density, and urban-rural migration. (b) indicators for employment need to be covered on labor force participation, unemployment, and new job creation. (c) indicators for housing need to be enhanced to residential quality improvement and slum upgrading. (d) indicators for transport need to be heightened to the public parking lot and sidewalk improvement. (e) indicators for safety need to be enhanced to construction safety and insurance services. (f) indicators for water use needs to be comprised of potable water accessible, water consumption rate, and reservoir conservation and maintenance. (g) indicators for air quality and energy need to be enhanced to fine dust level, urban forest areas, and energy consumption rate. (h) indicators for urban space and tourism need to be covered on urban park creation and maintenance, botanic garden preparation, and playground quality and management.

The UN Sustainable Development Goal 11 (SDG 11) indicators have correlations with nine consensus indicators. These indicators correlate with SCI1 (population density) in 'demography', SCI10 (unemployment rate) in 'employment', SCI17 (slum population) in 'housing', SCI23 (public transport sharing rate) in 'transport', SCI32 (disaster prevention) in 'safety', SCI38 (potable water supply) in 'water use', SCI45 (regular solid waste collection) in 'waste management', SCI55 (fine dust level) in 'air quality and energy', and SCI65 (conserved cultural, historical, and heritage buildings) in 'urban space and tourism'. This shows that the UN SDG 11 has nine indicators suitable for applying to Cambodia. However, when applying these indicators to Cambodia, their measurement 
should be revised for Cambodia's urban context. In this case, the consensus indicators and their explanations could be useful for this modification. Moreover, these correlated indicators of UN SDG 11 distribute in all categories of the consensus indicators. This shows that the consensus indicators' categories are appropriate to use for developing and/or classifying the sustainable city indicators for Cambodia towards achieving urban sustainability. Consequently, policymaking for the development and management of sustainable cities should focus on these categories and their consensus indicators. The policymaking processes must be involved by all relevant agencies, especially the agencies that have roles and responsibilities related to these categories and indicators. The most relevant agencies should play roles as implementing agencies for the development projects, and other relevant agencies could play roles as supporting or participating agencies.

Based on the findings of this research and the roles and responsibilities of the government agencies [8,93], the sectoral development of sustainable cities should be responsible by the Ministry of Planning (sustainable urban demographic management and improvement), Ministry of Labor and Vocational Training (sustainable urban employment development and management), Ministry of Land Management, Urban Planning, and Construction (sustainable urban housing development and urban spaces management), Ministry of Public Works and Transport (sustainable urban transport development and management), Ministry of Interior (sustainable urban safety system development and management), Ministry of Industry and Handicraft (sustainable urban water consumption and production improvement), Ministry of Environment (sustainable urban waste management, noise control, and air quality improvement), Ministry of Mines and Energy (sustainable urban energy consumption and production improvement), and Ministry of Tourism (sustainable urban tourism development and management). The other agencies which have roles and responsibilities related to the consensus indicators should be supporting and involving in the policymaking processes as well. The National Council for Sustainable Development (NCSD) should be responsible for the policy alignment for the inclusive development of sustainable cities. Most importantly, the NCSD should be responsible for the inclusive assessment of sustainable city development by coordinating with the above-mentioned nine sectoral responsible agencies. In this assessment, inclusive sustainable city indicators are needed. The indicators could be developed by upgrading the green and clean city indicators. The 32 consensus indicators could be the alternative indicators.

Based on the consensus indicators, policymaking for the development of sustainable cities should focus on (i) demography: Population growth and density, urban-rural migrations, and household economic conditions; (ii) employment: Labor force management and improvement, unemployment reduction, and new job creation; (iii) housing: Low-income house development, quality of living, and slum upgrading; (iv) transport: Public transport system and accessibility, parking lots and sidewalk improvement, traffic congestion reduction, and road infrastructure expansion; (v) safety: Crime prevention measure, disaster prevention facility, construction safety management, and insurance enhancement; (vi) water use: Potable water supply infrastructure improvement, sustainable water consumption and production, water reservoir creation, and natural water source conservation; (vii) waste management: Waste collection network, waste reduction and recycling, and wastewater treatment plant capacity improvement; (viii) air quality and energy: Air quality management and improvement, urban forest area conservation, efficient energy consumption and production, and renewable energy system improvement; and (ix) urban space and tourism: Urban park creation and management, botanic garden preparation, quality playground development, sport and leisure area enhancement, cultural, historical, and heritage building conservation, and tourism infrastructure and facility development.

Practically, Schumann (2016) argued that many aspects need to be considered to apply the indicators at the national level, particularly at the sub-national level; the role that indicators can play in encouraging cooperation among different sub-national governments should be taken into the account [94]. In this case, the departments and divisions of the above-mentioned responsible agencies at both sub-national and local levels could be the important agencies contributing to the efficient 
policymaking and play important roles in encouraging the local relevant stakeholders and residents to take part in the policymaking processes.

The above-mentioned findings and discussions could be useful to (i) the relevant institutions for making efficient policies, especially the policies for sectoral development, (ii) the development partners for seeking out collaboration with government agencies for sectoral development and inclusive assessment of sustainable cities in Cambodia, (iii) the National Council for Sustainable Development for clarifying roles and responsibilities between the sectoral development agencies, and for collaborating on the inclusive assessment of sustainable city development in Cambodia, and (iv) the government for considerably applying the UN sustainable development goal 11 indicators to Cambodia, and transforming the green and clean city indicators to sustainable city indicators. The 32 consensus indicators could be used as alternative sustainable city indicators for Cambodia.

These findings and discussions could also be useful to future research on the development, management, and assessment of the sustainable cities in Cambodia, especially the specific fields of sustainable cities. The sectoral policies for sustainable city development could be further exploring and investigating, especially how to align the sustainable urban policies with the existing urban and relevant policies. The research on a framework of the sustainable city indicators seems to be required and the prioritization of the developed indicators seems to be essential as priority weight is necessary for the sectoral development and inclusive assessment of sustainable cities.

\section{Conclusions}

Through the Delphi processes of panel surveys, this research obtained 69 initial indicators in Round 1, 41 pre-validated indicators in Round 2, and 32 validated indicators in Round 3. All of the 32 indicators reached consensus. The confirmed levels of importance were all equal to or above 3.50. The consensus rates were all equal to or above $90.00 \%$. Based on the consensus indicators, the green and clean city indicators were found to be limited in terms of sustainability, especially in terms of 'housing, air quality, energy, demography, employment, and water use' indicators. The UN SDG 11 has nine indicators suitable for Cambodia. These indicators, however, should be modified when applying to Cambodia. The consensus indicators and their explanation would be useful for this modification. Moreover, the nine indicators distribute in all categories of the consensus indicators. These categories, therefore, could be appropriate to use for developing and/or classifying the sustainable city indicators for Cambodia towards achieving urban sustainability. Consequently, the nine categories, consensus indicators, and their explanation could be useful for policymaking for sustainable city development in Cambodia, especially policymaking for sectoral development.

This research suggests implications based on its lessons learned for future research as follows: In order to develop the indicators through Delphi processes of panel surveys which Round 1 conducts to develop the initial indicators, there should be at least two rounds for validating the initial indicators because (i) the statistical mean value from the group is very important for individual panelists to make the final decision to validate the indicators; and (ii) this situation can provide an opportunity for individuals to change their judgments based on statistical evident [57]. The consensus should be analyzed after the level of importance of the indicators is confirmed. It should be in Round 3 because (a) panelists provide judgments based on the mean value-the level of error is small, and (b) panelists get familiar with the indicators, due to three-time experiences- the judgment is accurate. In order to use the method more efficiently, a short time is efficient and identifying categories for panel surveys is a good option particularly, since the type of professional involved in this process is often busy. Especially, the availability of professional panelists and their willingness to join a panel must be considered in order to make sure they will be able to participate until the last round.

The levels of importance of the indicators in this research were verified to validate the indicators and to choose the significant indicators for Cambodia. Therefore, these levels of importance are not recommended to use for ranking or prioritizing the 32 consensus indicators. By the way, based on the method explained in Section 2.1, this research suggests future research to prioritize these 
indicators by using the ANP (analytic network process) or AHP (analytic hierarchy process) method. These two methods use pairwise comparison and generally require a number of respondents from relevant fields at least 100. The fields related to consensus indicators' categories are recommended. Based on the consensus indicators and their categories, this research discussed the sectoral policies and responsibilities of the government agencies for the development and assessment of sustainable cities in Cambodia. Consequently, we can see how aligning the consensus indicators into the existing urban and relevant policies is necessary, but beyond the scope of this research. Therefore, future research exploring this point would contribute to an inclusive policy alignment.

Author Contributions: Conceptualization, P.C. and M.-H.L.; Data Curation, P.C.; Formal Analysis, P.C.; Funding Acquisition, P.C. and M.-H.L.; Investigation, P.C.; Methodology, P.C. and M.-H.L.; Project Administration, P.C. and M.-H.L.; Resources, P.C. and M.-H.L.; Software, P.C.; Supervision, M.-H.L.; Validation, P.C. and M.-H.L.; Visualization, P.C. and M.-H.L.; Writing-Original Draft, P.C.; Writing-Review and Editing, P.C. and M.-H.L.

Funding: This research received no external funding.

Acknowledgments: The authors thank the Ministry of Environment, Department of Green Economy, and General Secretariat of the National Council for Sustainable Development (Cambodia) who administratively supported this research, provided the place for Delphi panel surveys, and helped invite the panelists, and the National Institute of International Education under the Ministry of Education (Korea) who has been providing doctoral research scholarships to P.C. which were allocated for this research.

Conflicts of Interest: The authors declare no conflict of interest. Even though the General Secretariat of the National Council for Sustainable Development helped invite the panelists and the Ministry of Environment provided the place for the panels, they had no role in the design of this research, interpretation of the data, discussion of the results, and preparation and revision of the manuscript.

\section{Appendix A. Delphi Technique}

Table A1. Summary of Delphi technique.

\begin{tabular}{ll}
\hline Section & \multicolumn{1}{c}{ Explanation } \\
\hline \multirow{3}{*}{ Background } & $\begin{array}{l}\text { Delphi technique was developed during the 1950s by workers at the RAND Corporation } \\
\text { while involved in a US Air Force sponsored project [56,57] and it is used as a systematic } \\
\text { procedure to evoke expert opinion and usually conducted through a series of } \\
\text { questionnaires [58-61]. It has become a widely used tool for measuring and aiding } \\
\text { forecasting and decision making in a variety of disciplines [57,62]. }\end{array}$ \\
& $\begin{array}{l}\text { Delphi method had been used in many areas and can be used for any purpose requiring } \\
\text { the use of committees [58-62]. Based on many studies, Sourani and Sohail (2015) presented } \\
\text { Pelphi as useful to (a) obtain accurate information that is unavailable, (b) handle complex } \\
\text { problems that require more judgmental analysis, (c) define areas where there is } \\
\text { considerable uncertainty and/or a lack of agreed knowledge or disagreement, (d) allow for } \\
\text { combining fragmentary perspectives into a collective understanding, (e) model a } \\
\text { real-world phenomenon involving a range of viewpoints and for which there is little } \\
\text { established quantitative evidence, and (f) highlight topics of concern and assess } \\
\text { uncertainty in a quantitative manner [63-77]. }\end{array}$ \\
$\begin{array}{l}\text { Delphi technique has three main characteristics: (1) Anonymity allows individuals to } \\
\text { provide their opinions and judgments through questionnaires; (2) iteration gives }\end{array}$ \\
$\begin{array}{l}\text { opportunity to individuals to change their opinions and judgments; and (3) statistical } \\
\text { response provides the previous round opinions and judgments through simple statistical } \\
\text { summary (a mean or median value) [56-63]. These characteristics are necessary to define } \\
\text { the attributes of the Delphi procedure, although there are numerous ways in which they } \\
\text { may be applied [57]. Furthermore, the processes continues for a pre-determined number of } \\
\text { rounds or until some predetermined criterion has been met, e.g., reaching consensus } \\
\text { (see Figure A1) [63]. }\end{array}$ \\
\hline Characteristics \\
\hline
\end{tabular}


Table A1. Cont.

\begin{tabular}{|c|c|}
\hline Section & Explanation \\
\hline $\begin{array}{c}\text { Selection of } \\
\text { panelists }\end{array}$ & $\begin{array}{l}\text { Delphi technique generally uses expertise panel. Martino (1983) argued that an expert may } \\
\text { be defined in broad terms as 'someone who has special knowledge about the specific } \\
\text { subject' [58] (p. 27). Furthermore, key criteria for selecting the experts to participate in a } \\
\text { Delphi process of panel surveys are knowledge; however, criteria of willingness and } \\
\text { availability to participate are also important to consider }[58,61,78] \text {. This attribute may be } \\
\text { considered secondary to the knowledge or degree of expertness }[58,63] \text {. }\end{array}$ \\
\hline $\begin{array}{c}\text { Number of } \\
\text { panelists }\end{array}$ & $\begin{array}{l}\text { In general, Delphi studies use different sizes of panels [63]. Weidman and colleagues (2011) } \\
\text { did not specify the number of experts needed for a Delphi study; however, it is recognized } \\
\text { that a minimum appropriate size would include } 7 \text { or } 8 \text { experts [79]. Mitchell and } \\
\text { McGoldrick (1994) argued that the size should be no less than } 8 \text { to } 10 \text { members [38]. } \\
\text { Hallowell and Gambatese (2010) mentioned that most studies incorporated } 8 \text { to } 16 \text { experts } \\
\text { and suggested a minimum of } 8 \text { and they also argued that the specific number should be } \\
\text { determined by the research characteristics }[63,78,80] \text {. }\end{array}$ \\
\hline $\begin{array}{l}\text { Number of } \\
\text { rounds }\end{array}$ & $\begin{array}{l}\text { Number of rounds in Delphi studies is varied. Chong and Zin }(2010) \text { argued that the } \\
\text { number of rounds should be based on the objectives of research }[63,81] \text {. Gunhan and } \\
\text { Arditi (2005) mentioned that most changes in responses took place in the first two rounds } \\
\text { and that little was gained after that }[63,82] \text {. Hallowell and Gambatese }(2010) \text { presented the } \\
\text { advantage of having a three-round Delphi, which facilitates obtaining reasons for outlying } \\
\text { responses from Round } 2 \text { and reporting these in Round 3; such a process could facilitate the } \\
\text { consideration of all options and the attainment of a consensus about the correct value } \\
\text { instead of conforming to an incorrect opinion }[63,78] \text {. }\end{array}$ \\
\hline Time consuming & $\begin{array}{l}\text { By using a Delphi method to develop the agreed set of economic sustainability criteria that } \\
\text { should be addressed in a procumbent strategy, Sourani and Sohail (2015) argued that } \\
\text { Delphi could be time-consuming for participating experts because the experts are busy } \\
\text { people. With the need for them to respond to several rounds, there is a considerable risk of } \\
\text { drop out by some of them. A sufficient number of experts should, therefore, be appointed. } \\
\text { Measures to reduce possible fatigue should be considered, including proper research } \\
\text { design [63]. }\end{array}$ \\
\hline Consensus & $\begin{array}{l}\text { From a review of a wide range of Delphi studies, it is shown that authors measured } \\
\text { consensus in different ways. Jones and Hunter [83] and Hughes [84] argued that the } \\
\text { purpose of measuring consensus is to determine the extent to which experts agree about a } \\
\text { given issue. Quite commonly, the extent of consensus was measured by the percentages of } \\
\text { respondents agreeing on certain answers; for example, Sourani and Sohail [63] argued that } \\
\text { based on a 5-point Likert-type scale, the certain criterion can be established based on } \\
\text { having } 75 \% \text { or more of the respondents agreeing on giving a ranking that is equal to or } \\
\text { above 3. }\end{array}$ \\
\hline
\end{tabular}



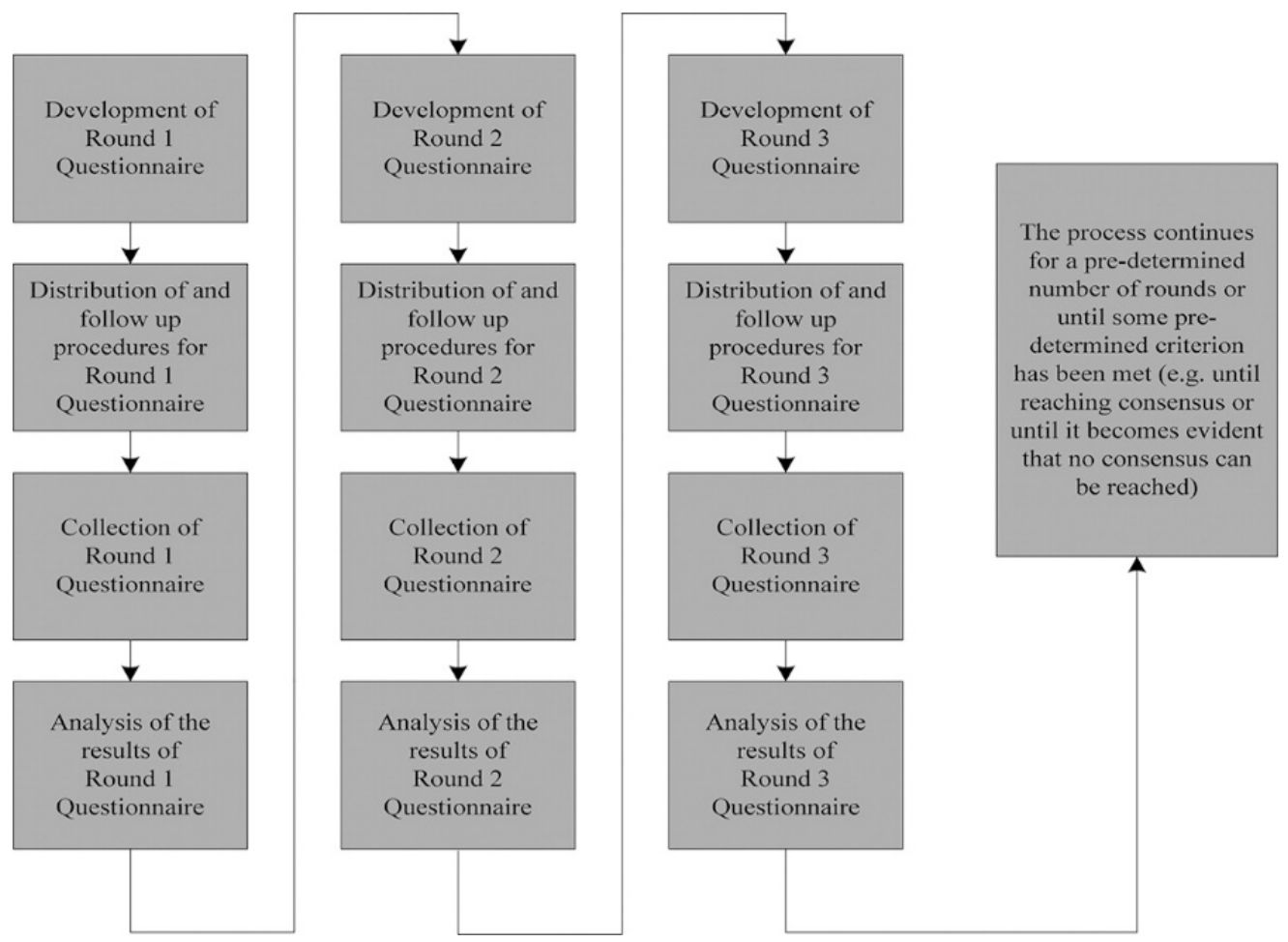

Figure A1. Delphi processes. Source: Sourani and Sohail (2015).

\section{Appendix B. Delphi Results and Consensus}

Table A2. Results of Delphi three rounds and consensus.

\begin{tabular}{|c|c|c|c|c|c|c|c|c|c|}
\hline \multirow{2}{*}{ Category } & \multirow{2}{*}{ Indicator } & \multicolumn{2}{|c|}{ Round 1} & \multicolumn{2}{|c|}{ Round 2} & \multicolumn{2}{|c|}{ Round 3} & \multirow{2}{*}{\multicolumn{2}{|c|}{$\begin{array}{c}\text { Consensus } \geq 3 \\
\text { and } \geq 75 \%\end{array}$}} \\
\hline & & $\mathbf{N}$ & $\%$ & Mean & SD & Mean & SD & & \\
\hline \multirow{8}{*}{ Demography } & SCI1 & 16 & 100 & 3.94 & 0.83 & 3.90 & 0.83 & 100.00 & $\sqrt{ }$ \\
\hline & $\mathrm{SCI} 2$ & 14 & 88 & 3.63 & 0.99 & 2.90 & 0.83 & $\mathrm{x}$ & $x$ \\
\hline & $\mathrm{SCI} 3$ & 14 & 88 & 3.88 & 0.99 & 4.20 & 0.60 & 100.00 & $\sqrt{ }$ \\
\hline & SCI4 & 13 & 81 & 2.94 & 0.75 & $x$ & $\mathrm{x}$ & $\mathrm{x}$ & $x$ \\
\hline & SCI5 & 10 & 63 & 2.88 & 0.60 & $x$ & $x$ & $x$ & $x$ \\
\hline & SCI6 & 5 & 31 & 3.81 & 0.88 & 3.60 & 0.92 & 90.00 & $\sqrt{ }$ \\
\hline & SCI7 & 3 & 19 & 2.75 & 0.90 & $x$ & $\mathrm{x}$ & $x$ & $x$ \\
\hline & SCI8 & 2 & 13 & 2.88 & 0.86 & $x$ & $x$ & $x$ & $x$ \\
\hline \multirow{7}{*}{ Employment } & SCI9 & 15 & 94 & 3.88 & 0.93 & 4.20 & 0.75 & 100.00 & $\sqrt{ }$ \\
\hline & SCI10 & 14 & 88 & 3.75 & 0.75 & 3.50 & 0.81 & 90.00 & $\sqrt{ }$ \\
\hline & SCI11 & 12 & 75 & 3.75 & 1.15 & 2.80 & 0.98 & $\mathrm{x}$ & $x$ \\
\hline & SCI12 & 11 & 69 & 4.06 & 0.90 & 4.60 & 0.49 & 100.00 & $\sqrt{ }$ \\
\hline & SCI13 & 7 & 44 & 2.81 & 1.18 & $x$ & $x$ & $\mathrm{x}$ & $x$ \\
\hline & SCI14 & 3 & 19 & 2.88 & 1.11 & $x$ & $x$ & $x$ & $x$ \\
\hline & SCI15 & 1 & 6 & 3.44 & 1.17 & 2.90 & 0.83 & $x$ & $x$ \\
\hline \multirow{7}{*}{ Housing } & SCI16 & 15 & 94 & 4.38 & 0.78 & 4.70 & 0.46 & 100.00 & $\sqrt{ }$ \\
\hline & SCI17 & 13 & 81 & 3.69 & 0.77 & 3.60 & 0.66 & 100.00 & $\sqrt{ }$ \\
\hline & SCI18 & 12 & 75 & 3.50 & 1.22 & 3.90 & 0.94 & 90.00 & $\sqrt{ }$ \\
\hline & SCI19 & 11 & 69 & 2.94 & 1.09 & $x$ & $\mathrm{x}$ & $x$ & $x$ \\
\hline & SCI20 & 9 & 56 & 2.88 & 0.78 & $x$ & $x$ & $x$ & $x$ \\
\hline & SCI21 & 4 & 25 & 2.69 & 0.92 & $x$ & $x$ & $x$ & $x$ \\
\hline & SCI22 & 2 & 13 & 2.94 & 0.83 & $x$ & $x$ & $x$ & $x$ \\
\hline
\end{tabular}


Table A2. Cont.

\begin{tabular}{|c|c|c|c|c|c|c|c|c|c|}
\hline \multirow{2}{*}{ Category } & \multirow{2}{*}{ Indicator } & \multicolumn{2}{|c|}{ Round 1} & \multicolumn{2}{|c|}{ Round 2} & \multicolumn{2}{|c|}{ Round 3} & \multirow{2}{*}{\multicolumn{2}{|c|}{$\begin{array}{c}\text { Consensus } \geq 3 \\
\text { and } \geq 75 \%\end{array}$}} \\
\hline & & $\mathbf{N}$ & $\%$ & Mean & SD & Mean & SD & & \\
\hline \multirow{8}{*}{ Transport } & SCI23 & 16 & 100 & 4.06 & 0.83 & 3.90 & 1.04 & 90.00 & $\sqrt{ }$ \\
\hline & SCI24 & 13 & 81 & 3.75 & 0.90 & 3.80 & 0.60 & 100.00 & $\sqrt{ }$ \\
\hline & SCI25 & 13 & 81 & 4.50 & 0.71 & 4.80 & 0.40 & 100.00 & $\sqrt{ }$ \\
\hline & SCI26 & 11 & 69 & 4.13 & 1.05 & 4.10 & 0.83 & 100.00 & $\sqrt{ }$ \\
\hline & SCI27 & 9 & 56 & 3.94 & 1.14 & 2.90 & 1.04 & $\mathrm{x}$ & $x$ \\
\hline & SCI28 & 8 & 50 & 2.94 & 1.03 & $x$ & $x$ & $x$ & $x$ \\
\hline & SCI29 & 3 & 19 & 2.88 & 1.11 & $x$ & $x$ & $x$ & $x$ \\
\hline & SCI30 & 1 & 6 & 2.75 & 1.25 & $x$ & $x$ & $x$ & $x$ \\
\hline \multirow{7}{*}{ Safety } & SCI31 & 16 & 100 & 3.94 & 0.90 & 4.20 & 0.75 & 100.00 & $\sqrt{ }$ \\
\hline & SCI32 & 14 & 88 & 3.63 & 0.86 & 3.70 & 0.64 & 100.00 & $\sqrt{ }$ \\
\hline & SCI33 & 10 & 63 & 3.94 & 1.09 & 3.90 & 0.70 & 100.00 & $\sqrt{ }$ \\
\hline & SCI34 & 9 & 56 & 3.63 & 1.05 & 3.50 & 0.67 & 100.00 & $\sqrt{ }$ \\
\hline & SCI35 & 6 & 38 & 2.63 & 0.86 & $x$ & $x$ & $\mathrm{x}$ & $x$ \\
\hline & SCI36 & 5 & 31 & 2.94 & 1.03 & $x$ & $x$ & $x$ & $x$ \\
\hline & SCI37 & 4 & 25 & 2.81 & 1.01 & $x$ & $x$ & $x$ & $x$ \\
\hline \multirow{7}{*}{ Water Use } & SCI38 & 14 & 88 & 4.63 & 0.60 & 4.60 & 0.49 & 100.00 & $\sqrt{ }$ \\
\hline & SCI39 & 13 & 81 & 2.94 & 1.03 & $x$ & $x$ & $x$ & $x$ \\
\hline & SCI40 & 12 & 75 & 4.00 & 0.94 & 3.90 & 0.70 & 100.00 & $\sqrt{ }$ \\
\hline & SCI41 & 10 & 63 & 4.31 & 0.77 & 4.50 & 0.67 & 100.00 & $\sqrt{ }$ \\
\hline & SCI42 & 7 & 44 & 4.19 & 0.88 & 2.70 & 0.78 & $\mathrm{x}$ & $x$ \\
\hline & SCI43 & 2 & 13 & 4.19 & 0.95 & 2.90 & 0.94 & $x$ & $x$ \\
\hline & SCI44 & 1 & 6 & 2.94 & 1.09 & $x$ & $x$ & $x$ & $x$ \\
\hline \multirow{8}{*}{$\begin{array}{c}\text { Waste } \\
\text { Management }\end{array}$} & SCI45 & 16 & 100 & 4.00 & 1.00 & 4.60 & 0.66 & 100.00 & $\sqrt{ }$ \\
\hline & SCI46 & 14 & 88 & 4.25 & 0.75 & 4.10 & 0.83 & 100.00 & $\sqrt{ }$ \\
\hline & SCI47 & 14 & 88 & 4.13 & 0.99 & 2.90 & 0.94 & $\mathrm{x}$ & $x$ \\
\hline & SCI48 & 12 & 75 & 3.94 & 0.90 & 4.30 & 0.78 & 100.00 & $\sqrt{ }$ \\
\hline & SCI49 & 7 & 44 & 2.88 & 0.93 & $x$ & $x$ & $\mathrm{x}$ & $x$ \\
\hline & SCI50 & 5 & 31 & 2.94 & 1.09 & $x$ & $x$ & $x$ & $x$ \\
\hline & SCI51 & 3 & 19 & 2.94 & 0.90 & $x$ & $x$ & $x$ & $x$ \\
\hline & SCI52 & 2 & 13 & 2.88 & 0.99 & $x$ & $x$ & $x$ & $x$ \\
\hline \multirow{8}{*}{$\begin{array}{c}\text { Noise, Air } \\
\text { Quality and } \\
\text { Energy }\end{array}$} & SCI53 & 14 & 88 & 4.25 & 0.83 & 3.90 & 0.70 & 100.00 & $\sqrt{ }$ \\
\hline & SCI54 & 14 & 88 & 4.44 & 0.61 & 4.50 & 0.67 & 100.00 & $\sqrt{ }$ \\
\hline & SCI55 & 12 & 75 & 4.00 & 1.22 & 4.60 & 0.49 & 100.00 & $\sqrt{ }$ \\
\hline & SCI56 & 11 & 69 & 3.94 & 0.83 & 2.80 & 1.08 & $\mathrm{x}$ & $x$ \\
\hline & SCI57 & 6 & 38 & 2.94 & 1.30 & $x$ & $x$ & $\mathrm{x}$ & $x$ \\
\hline & SCI58 & 4 & 25 & 4.19 & 0.88 & 3.70 & 0.64 & 100.00 & $\sqrt{ }$ \\
\hline & SCI59 & 3 & 19 & 2.94 & 0.97 & $x$ & $x$ & $\mathrm{x}$ & $x$ \\
\hline & SCI60 & 2 & 13 & 2.81 & 0.63 & $x$ & $x$ & $x$ & $x$ \\
\hline \multirow{9}{*}{$\begin{array}{l}\text { Urban Space } \\
\text { and Tourism }\end{array}$} & SCI61 & 15 & 94 & 2.94 & 0.83 & $x$ & $x$ & $x$ & $x$ \\
\hline & SCI62 & 13 & 81 & 4.19 & 1.07 & 4.10 & 0.83 & 100.00 & $\sqrt{ }$ \\
\hline & SCI63 & 12 & 75 & 2.69 & 0.58 & $x$ & $x$ & $\mathrm{x}$ & $\mathrm{x}$ \\
\hline & SCI64 & 9 & 56 & 4.00 & 0.71 & 4.00 & 0.77 & 100.00 & $\sqrt{ }$ \\
\hline & SCI65 & 4 & 25 & 3.06 & 0.75 & 3.70 & 0.90 & 100.00 & $\sqrt{ }$ \\
\hline & SCI66 & 3 & 19 & 3.00 & 0.79 & 2.90 & 1.04 & $\mathrm{x}$ & $x$ \\
\hline & SCI67 & 3 & 19 & 4.06 & 0.83 & 4.10 & 0.70 & 100.00 & $\sqrt{ }$ \\
\hline & SCI68 & 2 & 13 & 4.00 & 0.94 & 3.60 & 0.80 & 100.00 & $\sqrt{ }$ \\
\hline & SCI69 & 1 & 6 & 2.63 & 0.70 & $x$ & $x$ & $\mathrm{x}$ & $x$ \\
\hline
\end{tabular}

Note: " $\sqrt{ }$ " refers to 'confirmed level of importance and reached consensus'; " $x$ " refers to 'did not confirm level of importance' and/or 'did not reach consensus'. 
Table A3. Consensus indicators and their explanations.

\begin{tabular}{|c|c|c|}
\hline Category & Indicator & Explanation \\
\hline \multirow{3}{*}{ Demography } & $\begin{array}{l}\text { SCI3: Average of } \\
\text { household income }\end{array}$ & $\begin{array}{l}\text { This indicator assesses the economic conditions of households } \\
\text { living in the city. It measures household income on average. This } \\
\text { measurement can be divided by the specific blocks of the city, } \\
\text { such as Krom (village), Sangkat (commune) or Khan (district). }\end{array}$ \\
\hline & $\begin{array}{l}\text { SCI1: Population } \\
\text { density }\end{array}$ & $\begin{array}{l}\text { This indicator assesses the population density in the city. } \\
\text { (Population density is related to population growth and land } \\
\text { use planning. In the case of high density, population growth } \\
\text { needs to be well managed and land use planning needs to be } \\
\text { advanced.) }\end{array}$ \\
\hline & $\begin{array}{l}\text { SCI6: Percentage of the } \\
\text { population migrating } \\
\text { into the city }\end{array}$ & $\begin{array}{l}\text { This indicator assesses the migration rate into the city per year } \\
\text { on average. If the data is not available, the population growth } \\
\text { rate can be an alternative indicator. (Highly increasing } \\
\text { migration into the cities, especially the capital will be resulting } \\
\text { in slums, homeless, jobless, crimes etc.) }\end{array}$ \\
\hline \multirow{3}{*}{ Employment } & $\begin{array}{l}\text { SCI9: Labor force } \\
\text { participation rate }\end{array}$ & $\begin{array}{l}\text { This indicator assesses the total population in the labor force } \\
\text { both the employed and unemployed population, excluding the } \\
\text { housewives and the jobless population who are not looking for } \\
\text { work, such as stay-at-home moms, retirees, and students. }\end{array}$ \\
\hline & $\begin{array}{l}\text { SCI10: Unemployment } \\
\text { rate }\end{array}$ & $\begin{array}{l}\text { This indicator assesses the unemployment rate in the city. (More } \\
\text { unemployed workers mean less economic production. The } \\
\text { economy with high unemployment has a lower output without } \\
\text { a proportional decline in the need for basic consumption. High } \\
\text { persistent unemployment can signal serious distress in an } \\
\text { economy and even lead to social and political upheaval.) }\end{array}$ \\
\hline & $\begin{array}{l}\text { SCI12: Number of new } \\
\text { jobs created per year }\end{array}$ & $\begin{array}{l}\text { This indicator assesses the city government's efforts in creating } \\
\text { new jobs for its residents. It measures the number of new jobs } \\
\text { created per year on average. The types and size of new job } \\
\text { created are all assessed. (Creating new jobs would be a solution } \\
\text { to reduce the unemployment rate in the city.) }\end{array}$ \\
\hline \multirow{3}{*}{ Housing } & $\begin{array}{l}\text { SCI17: Percentage of } \\
\text { the population living in } \\
\text { slums }\end{array}$ & $\begin{array}{l}\text { This indicator assesses the slum situation in the city. It measures } \\
\text { the percentage of the population living in slums or informal } \\
\text { settlement compared to the total population in the city. (Slum } \\
\text { upgrading and informal settlement prohibition are important for } \\
\text { the attractiveness of the city and the improvement in the quality } \\
\text { of life. }\end{array}$ \\
\hline & $\begin{array}{l}\text { SCI16: Number of } \\
\text { low-income housing } \\
\text { development projects }\end{array}$ & $\begin{array}{l}\text { This indicator assesses the city government's efforts in } \\
\text { providing affordable housing to its residents. It measures the } \\
\text { number of low-income housing development projects, both } \\
\text { completed and ongoing projects. The types and size of the } \\
\text { projects are also assessed. (Low-income housing development } \\
\text { would be a solution to reduce slums and informal settlements.) }\end{array}$ \\
\hline & $\begin{array}{l}\text { SCI18: Percentage of } \\
\text { new residential } \\
\text { buildings (aged less } \\
\text { than } 30 \text { years) }\end{array}$ & $\begin{array}{l}\text { This indicator assesses the quality of residential buildings by the } \\
\text { percentage of new buildings (aged less than } 30 \text { years old) } \\
\text { compared to the total residential buildings in the city. It is the } \\
\text { opposite indicator of aging residential buildings. If new } \\
\text { buildings are much less than old buildings, redevelopment or } \\
\text { regeneration is needed in order to improve the housing quality, } \\
\text { environment, and image of the city. }\end{array}$ \\
\hline
\end{tabular}


Table A3. Cont.

\begin{tabular}{|c|c|c|}
\hline Category & Indicator & Explanation \\
\hline \multirow{4}{*}{ Transport } & $\begin{array}{l}\text { SCI23: Public transport } \\
\text { sharing rate }\end{array}$ & $\begin{array}{l}\text { This indicator assesses public transport by the percentage of } \\
\text { public transport means compared to the total transport means in } \\
\text { the city. (Public transport helps reduce the uses of individual } \\
\text { cars which is very significant in reducing traffic congestion and } \\
\text { greenhouse gas.) }\end{array}$ \\
\hline & $\begin{array}{l}\text { SCI25: Number of } \\
\text { initiatives for sidewalk } \\
\text { improvement }\end{array}$ & $\begin{array}{l}\text { This indicator assesses the city government's efforts in } \\
\text { improving sidewalks for pedestrians. It measures the number of } \\
\text { initiated programs or activities of the city government for } \\
\text { improving sidewalks. The types and size of initiated programs } \\
\text { or activities are also assessed. }\end{array}$ \\
\hline & $\begin{array}{l}\text { SCI26: Number of } \\
\text { public parking lots in } \\
\text { the city }\end{array}$ & $\begin{array}{l}\text { This indicator assesses the sufficiency of public parking lots in } \\
\text { the city, including the city's government efforts in enhancing } \\
\text { public parking lots. It measures the number of public parking } \\
\text { lots in the city by Krom, Sangkat, or Khan. The types and size of } \\
\text { the public parking lots are also assessed. }\end{array}$ \\
\hline & $\begin{array}{l}\text { SCI24: Number of } \\
\text { initiatives to reduce } \\
\text { traffic congestion }\end{array}$ & $\begin{array}{l}\text { This indicator assesses the city government's efforts in reducing } \\
\text { traffic congestion. It measures the number of initiatives of the } \\
\text { city government to reduce traffic congestion, such as road } \\
\text { infrastructure expansion and improvement, traffic system } \\
\text { management, etc. The types and size of the initiatives are also } \\
\text { assessed. }\end{array}$ \\
\hline \multirow{4}{*}{ Safety } & $\begin{array}{l}\text { SCI31: Number of } \\
\text { measures or initiatives } \\
\text { to prevent crimes }\end{array}$ & $\begin{array}{l}\text { This indicator assesses the city government's efforts in } \\
\text { preventing crimes. It measures the number of measures or } \\
\text { initiatives of the city government to prevent crimes. The types of } \\
\text { initiatives or measures are also assessed. }\end{array}$ \\
\hline & $\begin{array}{l}\text { SCI33: Number of } \\
\text { initiated programs to } \\
\text { protect workers or road } \\
\text { users from construction } \\
\text { risks }\end{array}$ & $\begin{array}{l}\text { This indicator assesses the city government's efforts in } \\
\text { preventing construction risks. It measures the number of } \\
\text { initiated programs to protect construction workers or road users } \\
\text { from construction risks. The types and size of the programs are } \\
\text { also assessed. }\end{array}$ \\
\hline & $\begin{array}{l}\text { SCI32: Number of } \\
\text { facilities to prevent } \\
\text { disasters }\end{array}$ & $\begin{array}{l}\text { This indicator assesses the availability of disaster prevention } \\
\text { facilities in the city. It measures the number of prevention } \\
\text { facilities, such as constructed dams or reservoirs, pumping } \\
\text { stations, fire trucks, etc. The types and size of the prevention } \\
\text { facilities are also assessed. }\end{array}$ \\
\hline & $\begin{array}{l}\text { SCI34: Percentage of } \\
\text { residents using } \\
\text { insurance services; } \\
\text { number of insurance } \\
\text { companies }\end{array}$ & $\begin{array}{l}\text { This indicator assesses the insurance used by the residents in the } \\
\text { city, including the services and quality. It measures the } \\
\text { percentage of residents using insurance services compared to } \\
\text { total population in the city. It also measures the sufficiency of } \\
\text { the insurance companies providing services in the city. }\end{array}$ \\
\hline \multirow{3}{*}{ Water Use } & $\begin{array}{l}\text { SCI38: Percentage of } \\
\text { households with access } \\
\text { to potable water } \\
\text { infrastructure }\end{array}$ & $\begin{array}{l}\text { This indicator assesses the potable water supply accessibility in } \\
\text { the city. It measures the percentage of households with } \\
\text { accessing to potable water supply infrastructure compared to } \\
\text { total households in the city. (Potable water is considered in } \\
\text { terms of both water security and sanitation.) }\end{array}$ \\
\hline & $\begin{array}{l}\text { SCI41: Average of the } \\
\text { water consumption rate } \\
\text { per person or } \\
\text { household }\end{array}$ & $\begin{array}{l}\text { This indicator assesses the level of water consumption in the city. } \\
\text { It measures the water consumption rate per person or household } \\
\text { per day on average. (It is also to understand the ratio of water } \\
\text { consumption compared to the total water supply in the city.) }\end{array}$ \\
\hline & $\begin{array}{l}\text { SCI40: Number of } \\
\text { natural or artificial } \\
\text { reservoirs in or nearby } \\
\text { the city }\end{array}$ & $\begin{array}{l}\text { This indicator assesses the availability of fresh water sources in } \\
\text { the city. It measures the number and size of natural or artificial } \\
\text { reservoirs in or nearby the city. It is significant to understand the } \\
\text { situation of water supply in the city, especially in the dry season } \\
\text { (sufficiency or not). }\end{array}$ \\
\hline
\end{tabular}


Table A3. Cont.

\begin{tabular}{|c|c|c|}
\hline Category & Indicator & Explanation \\
\hline \multirow{3}{*}{$\begin{array}{c}\text { Waste } \\
\text { Management }\end{array}$} & $\begin{array}{l}\text { SCI45: Percentage of } \\
\text { solid waste regularly } \\
\text { collected }\end{array}$ & $\begin{array}{l}\text { This indicator assesses the public organizations in place, } \\
\text { especially the city government's efforts in collecting solid waste. } \\
\text { It measures the percentage of households linked to the network } \\
\text { that disposes of solid waste compared to the total household in } \\
\text { the city. }\end{array}$ \\
\hline & $\begin{array}{l}\text { SCI46: Capacity of } \\
\text { wastewater treatment } \\
\text { plants in the city }\end{array}$ & $\begin{array}{l}\text { This indicator assesses the capacity of the wastewater treatment } \\
\text { plants in the city. It measures the capacity of the plants that can } \\
\text { treat the amount of wastewater per day comparable to total } \\
\text { population in that area. The number and types of plants are also } \\
\text { assessed. }\end{array}$ \\
\hline & $\begin{array}{l}\text { SCI48: Number of } \\
\text { initiatives to reduce } \\
\text { wastes }\end{array}$ & $\begin{array}{l}\text { This indicator assesses the city government's efforts in reducing } \\
\text { wastes. It measures the number of initiated programs or } \\
\text { activities to reduce waste, such as the } 3 \mathrm{R} \text { (reduce, reduce and } \\
\text { recycle) strategy. The types and size of the programs or activities } \\
\text { are also assessed. }\end{array}$ \\
\hline \multirow{4}{*}{$\begin{array}{l}\text { Air Quality and } \\
\text { Energy }\end{array}$} & SCI55: Fine dust levels & $\begin{array}{l}\text { This indicator assesses the level of fine dust in the city per day or } \\
\text { week. It measures the level of PM } 2.5 \text { or PM } 10 \text {. (The } \\
\text { measurement of the air quality in the city is very important in } \\
\text { order to provide the information about the air quality on time to } \\
\text { the residents.) }\end{array}$ \\
\hline & $\begin{array}{l}\text { SCI54: Percentage of } \\
\text { the urban forest }\end{array}$ & $\begin{array}{l}\text { This indicator assesses the conservation of urban forest. It } \\
\text { measures the ratio of conserved forest area compared to the total } \\
\text { area of the city. (Urban forests play an important role in } \\
\text { reducing the urban heat island effect, providing the canopies, } \\
\text { healing human's feelings etc.) }\end{array}$ \\
\hline & $\begin{array}{l}\text { SCI53: Average of the } \\
\text { energy consumption } \\
\text { rate per person or } \\
\text { household }\end{array}$ & $\begin{array}{l}\text { This indicator assesses the level of energy consumption in the } \\
\text { city. It measures the energy consumption rate per person or } \\
\text { household per day on average. (This indicator is also important } \\
\text { to understand the ratio of energy consumption compared to the } \\
\text { total energy supply in the city.) }\end{array}$ \\
\hline & $\begin{array}{l}\text { SCI58: Percentage of } \\
\text { renewable energy } \\
\text { contributed to the } \\
\text { electricity supply }\end{array}$ & $\begin{array}{l}\text { This indicator assesses the use of renewable energy in the city. It } \\
\text { measures the percentage of renewable energy contributed to the } \\
\text { electricity supply. (It is also to understand the city's government } \\
\text { efforts in promoting renewable energy consumption and } \\
\text { production.) }\end{array}$ \\
\hline \multirow{3}{*}{$\begin{array}{l}\text { Urban Space } \\
\text { and Tourism }\end{array}$} & $\begin{array}{l}\text { SCI62: Number of } \\
\text { natural or artificial } \\
\text { parks in the city }\end{array}$ & $\begin{array}{l}\text { This indicator assesses the sufficiency of parks in the city. It } \\
\text { measures the number of natural or artificial parks in the city. } \\
\text { The types and size of the parks are also assessed. (Urban parks } \\
\text { are the important public and green spaces in the city, generally } \\
\text { used as communal spaces.) }\end{array}$ \\
\hline & $\begin{array}{l}\text { SCI67: Number of } \\
\text { botanic gardens in the } \\
\text { city }\end{array}$ & $\begin{array}{l}\text { This indicator assesses the availability of botanic gardens in the } \\
\text { city to promote biodiversity education and tourism. It measures } \\
\text { by the number of botanic gardens in the city. The types and size } \\
\text { of the gardens are also assessed. (Botanic gardens are generally } \\
\text { created to conserve the local biodiversity and present it to the } \\
\text { tourists.) }\end{array}$ \\
\hline & $\begin{array}{l}\text { SCI65: Number of } \\
\text { conserved cultural, } \\
\text { historical, and heritage } \\
\text { buildings }\end{array}$ & $\begin{array}{l}\text { This indicator assesses the conservation of cultural, historical, } \\
\text { and heritage buildings in the city. It measures the number of the } \\
\text { conserved cultural, historical, and heritage buildings in the city. } \\
\text { The types and values of buildings are also assessed. }\end{array}$ \\
\hline
\end{tabular}


Table A3. Cont.

\begin{tabular}{ll}
\hline \multicolumn{1}{c}{ Indicator } & \multicolumn{1}{c}{ Explanation } \\
\hline $\begin{array}{l}\text { SCI64: Tourism growth } \\
\text { rate per year }\end{array}$ & $\begin{array}{l}\text { This indicator assesses the growth of tourism, including the } \\
\text { satisfaction of tourists which is also related to the city } \\
\text { government's efforts in attracting tourists. It measures the } \\
\text { tourism growth rate per year. (The level of tourists' satisfaction } \\
\text { could also be an important indicator.) }\end{array}$ \\
\hline $\begin{array}{l}\text { SCI68: Number of } \\
\text { playgrounds in the city }\end{array}$ & $\begin{array}{l}\text { This indicator assesses the availability of playgrounds in the city. } \\
\text { It measures the number of playgrounds by Krom, Sangkat or } \\
\text { Khan. The types and size of the playgrounds are also assessed. } \\
\text { (Playgrounds are the popularly public leisure areas, especially } \\
\text { for children.) }\end{array}$ \\
\hline
\end{tabular}

\section{References}

1. Royal Government of Cambodia, MoE. The National Green Growth Roadmap. 2009. Available online: http://www.asialeds.org/sites/default/files/resource/file/Final\%20Draft\%20Roadmap,\%20Feb26-2010.pdf (accessed on 14 February 2019).

2. Essam, Y.M.; Shannon, W.; Gary, K. Making Growth Green and Inclusive: The Case of Cambodia; OECD Green Growth Papers; OECD Publishing: Paris, France, 2013; Volume 9.

3. Cambodian National Assembly. The Law on the Ratification of the Kingdom of Cambodia to the Agreement on the Establishment of the Global Green Growth Institute. 2012. Available online: http://www.nationalassembly.org.kh/tv/kh/ViewLawFile.aspx?LawDID=419 (accessed on 14 February 2019).

4. GGGI. The Agreement on the Establishment of the Global Green Growth Institute. 2012. Available online: http://gggi.org/site/assets/uploads/2017/10/Agreement-on-the-Establishment-of-the-GGGI.pdf (accessed on 14 February 2019).

5. Cambodian Ministry of Royal Palace. The Royal Decree on the Establishment of the National Council on Green Growth; Ministry of Royal Palace: Phnom Penh, Cambodia, 2012.

6. Royal Government of Cambodia. The National Policy on Green Growth. 2013. Available online: http://www. greengrowthknowledge.org/national-documents/cambodia-national-policy-green-growth (accessed on 14 February 2019).

7. Royal Government of Cambodia. The National Strategic Plan on Green Growth 2013-2030. 2013. Available online: https://policy.asiapacificenergy.org/ru/node/2806 (accessed on 14 January 2019).

8. Cambodian Ministry of Royal Palace. The Royal Decree on the Establishment of the National Council for Sustainable Development; Ministry of Royal Palace: Phnom Penh, Cambodia, 2015.

9. NCSD; GGGI; ICEM. The Green City Strategic Planning Methodology. 2016. Available online: http://gggi.org/wp-content/uploads/2016/08/Annex-A-AAS1507-REP-006-Final-Green-city-strategicplanning-methodology.pdf (accessed on 14 January 2019).

10. Royal Government of Cambodia, NCSD. The Environment and Natural Resources Code of Cambodia: Revised Ninth Draft (Draft 9.1); NCSD: Phnom Penh, Cambodia, 2017.

11. United Nations-General Assembly. Transforming Our World: The 2030 Agenda for Sustainable Development; Resolution adopted by the General Assembly; United Nations: New York, NY, USA, 2015.

12. UN-Habitat. SDG Goal 11 Monitoring Framework. 2016. Available online: http://unhabitat.org/sdg-goal-11monitoring-framework/ (accessed on 14 February 2019).

13. Aapo, H.; Peter, B.; Miimu, A. Comparative analysis of standardized indicators for smart sustainable cities: What indicators and standards to use and when? J. Cities 2019, 89, 141-153.

14. Jacqueline, M.K.; Danielle, L.P. The urban sustainable development goal: Indicators, complexity and the politics of measuring cities. J. Cities 2017, 63, 92-97.

15. Royal Government of Cambodia, NCCCA. The Clean City Standard. 2012. Available online: http: //www.cambodiacleancity.gov.kh/kh/documents (accessed on 21 January 2019). (In Khmer)

16. NCSD; GGGI; ICEM. The Phnom Penh Green City Strategic Plan 2017-2026 and List of Priority Green City Investment Projects for Phnom Penh; NCSD: Phnom Penh, Cambodia, 2016; pp. 11-13. 
17. Baker, J.L.; Kikutake, N.; Lin, S.X.; Johnson, E.C.; Yin, S.; Ou, N. Urban Development in Phnom Penh (English); World Bank Group: Washington, DC, USA, 2017; pp. 40-41.

18. Erling, H.; Kristin, L.; David, B. Sustainable development: Our common future revisited. J. Glob. Environ. Chang. 2014, 26, 130-139.

19. Holden, E. Achieving Sustainable Mobility: Everyday and Leisure-Time Travel in the EU; Ashgate: Aldershot, UK, 2007.

20. Elkington, J. Enter the triple bottom line. In The Triple Bottom Line. Does It All Add Up? Henriques, A., Richardson, J., Eds.; Earthscan: London, UK, 2004; pp. 1-16.

21. Remigijus, C.; Jolita, R.; Bronislovas, M. The concept of sustainable development and its use for sustainability scenarios. J. Eng. Econ. 2009, 2, 28-37.

22. Artur, P. How many dimensions does sustainable development have? J. Sustain. Dev. 2008, 16, 81-91.

23. Georges, A.T.; Juste, R.; Jean, F.L.; Paul, L. Measuring the sustainability of cities: An analysis of the use of local indicators. J. Ecol. Indic. 2010, 10, 407-418.

24. Winter, M.; Knemeyer, A.M. Exploring the integration of sustainability and supply chain management current state and opportunities for future inquiry. Int. J. Phys. Distrib. Logist. Manag. 2013, 43, 18-38. [CrossRef]

25. Jonathan, G.; Fu, J.; Yu, G.; Steve, B. The role of supply chain leadership in the learning of sustainable practice: Toward an integrated framework. J. Clean. Prod. 2016, 137, 1458-1469.

26. UNDP. Sustainability and Equity: A Better Future for All. Human Development Report 2011. Available online: https://papers.ssrn.com/sol3/papers.cfm?abstract_id=2294671 (accessed on 14 February 2019).

27. Hák, T.; Janoušková, S.; Moldan, B. Sustainable development goals: A need for relevant indicators. J. Ecol. Indic. 2016, 60, 565-573. [CrossRef]

28. Robert, C.; Lew, D.; Lorenzo, F.; Enrico, G.; Ida, K.; Lars, F.M.; Kate, E.P.; Kristin, V.R.; Roberto, D.V.; Richard, W. Modelling and measuring sustainable wellbeing in connection with the UN sustainable development goals. J. Ecol. Econ. 2016, 130, 350-355.

29. Chaitanya, K.; Aromar, R.; Jessica, E.; Holger, K. Getting Started with the SDGs in Cities A Guide for Stakeholders. 2016. Available online: http://unsdsn.org/wp-content/uploads/2016/07/9.1.8.-Cities-SDGGuide.pdf (accessed on 21 April 2019).

30. United Nations. About the Sustainable Development Goals (17 Goals). Available online: https://un.org/ sustainabledevelopment/sustainable-development-goals/ (accessed on 11 January 2019).

31. UN-Habitat. SDG Goal 11 Monitoring Framework. A Guide to Assist National and Local Governments to Monitor \& Report on SDG 11 Indicators. 2016. Available online: https://unhabitat.org/wp-content/uploads/ 2016/02/SDG-Goal\%2011\%20Monitoring\%20Framework\%2025-02-16.pdf (accessed on 21 January 2019).

32. Royal Government of Cambodia, NCCCA. Why Clean City Contest? Available online: http://www. cambodiacleancity.gov.kh/kh (accessed on 14 January 2019). (In Khmer)

33. Royal Government of Cambodia, NCCCA. The Action Plan 2011-2014. Available online: http://www. cambodiacleancity.gov.kh/kh/documents (accessed on 14 January 2019). (In Khmer)

34. Luis, C.D.; Carlos, H.A.; Guilherme, D.; de Castro, N.; Lucca, Z. A multi-criteria approach to sort and rank policies based on Delphi qualitative assessments and ELECTRE TRI: The case of smart grids in Brazil. J. Omega 2018, 76, 100-111.

35. Mendoza, G.A.; Martins, H. Multi-criteria decision analysis in natural resource management: A critical review of methods and new modelling paradigms. J. For. Ecol. Manag. 2006, 230, 1-22. [CrossRef]

36. Belton, V.; Stewart, J.T. Multiple Criteria Decision Analysis. An Integrated Approach; Kluwer Academic Publishers: Boston, MA, USA, 2002.

37. Dyer, J.S. MAUT-Multi attribute utility theory. In Multiple Criteria Decision Analysis: State of the Art Surveys; Springer: New York, NY, USA, 2005; pp. 265-292.

38. Saaty, T.L. Analytic network process. In Encyclopedia of Operations Research and Management Science; Springer: New York, NY, USA, 2001; pp. 28-35.

39. Saaty, T. A scaling method for priorities in hierarchical structures. J. Math. Psychol. 1977, 15, $234-281$. [CrossRef]

40. Bana e Costa, C.; Vansnick, J. MACBETH: An interactive path towards the construction of cardinal value functions. Int. Trans. Oper. Res. 1994, 1, 387-500. [CrossRef] 
41. Hwang, C.L.; Yoon, K. Multiple Attribute Decision Making: Methods and Applications; Springer: Heidelberg, Germany, 1981.

42. Brans, J.P.; Vincke, P. Note-A preference ranking organisation method: The PROMETHEE method for multiple criteria decision-making. Manag. Sci. 1985, 31, 647-656. [CrossRef]

43. Guarini, M.R.; Battisti, F.; Chiovitti, A. Public initiatives of settlement transformation: A theoretical-methodological approach to selecting tools of multi-criteria decision analysis. Buildings 2018, 8, 1. [CrossRef]

44. Li, Y.; Thomas, M.A. A multiple criteria decision analysis (MCDA) software selection framework. In Proceedings of the 47th Hawaii International Conference on System Science (HICSS), Waikoloa, HI, USA, 6-9 January 2014; pp. 1084-1094.

45. Guarini, M.R.; Battisti, F.; Chiovitti, A. A methodology for the selection of multi-criteria decision analysis methods in real estate and land management processes. Sustainability 2018, 10, 507. [CrossRef]

46. Sepasgozar, S.M.E.; Davis, S. Construction Technology Adoption Cube: An Investigation on Process, Factors, Barriers, Drivers and Decision Makers Using NVivo and AHP Analysis. Buildings 2018, 8, 74. [CrossRef]

47. Kaspar, R.; Ossadnik, W. Evaluation of AHP software from a management accounting perspective. J. Model. Manag. 2013, 8, 305-319.

48. Baudry, G.; Macharis, C.; Vallée, T. Range-based multi-actor multi-criteria analysis: A combined method of multi-actor multi-criteria analysis and Monte Carlo simulation to support participatory decision making under uncertainty. Eur. J. Oper. Res. 2018, 264, 257-269. [CrossRef]

49. Wang, J.-J.; Jing, Y.-Y.; Zhang, C.-F.; Zhao, J.-H. Review on multi-criteria decision analysis aid in sustainable energy decision-making. Renew. Sustain. Energy Rev. 2009, 13, 2263-2278. [CrossRef]

50. Ribeiro, F.; Ferreira, P.; Araújo, M. Evaluating future scenarios for the power generation sector using a multi-criteria decision analysis (MCDA) tool: The Portuguese case. J. Energy 2013, 52, 126-136. [CrossRef]

51. Shen, Y.C.; Grace, T.R.L.; Tzeng, G.H. Combined DEMATEL techniques with novel MCDM for the organic light emitting diode technology selection. J. Expert Syst. Appl. 2011, 38, 1468-1481. [CrossRef]

52. Zhang, J. Evaluating regional low-carbon tourism strategies using the fuzzy delphi-analytic network process approach. J. Clean. Prod. 2017, 141, 409-419. [CrossRef]

53. Haruna, D.M.; Mohd, R.Y.; Ahmad, M.A.; Mohd, Y.I. Delphi method of developing environmental well-being indicators for the evaluation of urban sustainability in Malaysia. J. Procedia Environ. Sci. 2015, 30, $244-249$.

54. Sultana, I.; Ahmed, I.; Azeem, A. An integrated approach for multiple criteria supplier selection combining Fuzzy Delphi, Fuzzy AHP \& Fuzzy TOPSIS. J. Intell. Fuzzy Syst. 2015, 29, 1273-1287.

55. Chang, K.L. A hybrid program projects selection model for nonprofit TV stations. J. Math. Probl. Eng. 2015, 2015, 368212. [CrossRef]

56. Gene, R.; George, W. The Delphi technique as a forecasting tool: Issues and analysis. Int. J. Forecast. 1999, 15, 353-375.

57. Norman, D.; Olaf, H. An experimental application of the Delphi method to the use of experts. J. Manag. Sci. 1963, 9, 351-515.

58. Martino, J.P. Technological Forecasting for Decision-Making; North-Holland: Amsterdarn, The Nederland, 1983.

59. Linstone, H.A.; Turoff, M. The Delphi Techniques and Applications; Addison-Wesley: London, UK, 1975; Available online: https://web.njit.edu/ \{\}turoff/pubs/delphibook/delphibook.pdf (accessed on 11 January 2019).

60. Mullen, P.M. Delphi: Myths and reality. J. Health Organ. Manag. 2003, 17, 37-52. [CrossRef]

61. Robinson, J.B.L. Delphi methodology for economic impact assessment. J. Trans. Eng. 1991, 117, 335-349. [CrossRef]

62. Hill, K.Q.; Fowles, J. The methodological worth of the Delphi forecasting technique. J. Technol. Forecast. Soc. Chang. 1975, 7, 179-192. [CrossRef]

63. Sourani, A.; Sohail, M. The Delphi method: Review and use in construction management research. Int. J. Constr. Edu. Res. 2015, 11, 54-76. [CrossRef]

64. Jafari, A.; Valentin, V.; Bogus, S.M. Identification of Social Sustainability Criteria in Building Energy Retrofit Projects. J. Constr. Eng. Manag. 2019, 145, 04018136. [CrossRef]

65. Perveen, S.; Kamruzzaman, M.; Yigitcanlar, T. Developing policy scenarios for sustainable urban growth management: A Delphi approach. Sustainability 2017, 9, 1787. [CrossRef] 
66. Noh, H.-J.; Lee, S.-K.; Yu, J.-H. Identifying effective fugitive dust control measures for construction projects in Korea. Sustainability 2018, 10, 1206. [CrossRef]

67. Agrawal, T.K.; Pal, R. Traceability in textile and clothing supply chains: Classifying implementation factors and information sets via Delphi study. Sustainability 2019, 11, 1698. [CrossRef]

68. Dong, J.; Liu, D.; Wang, D.; Zhang, Q. Identification of key influencing factors of sustainable development for traditional power generation groups in a market by applying an extended MCDM model. Sustainability 2019, 11, 1754. [CrossRef]

69. Bastas, A.; Liyanage, K. ISO 9001 and supply chain integration principles based sustainable development: A Delphi study. Sustainability 2018, 10, 4569. [CrossRef]

70. Gupta, U.G.; Clarke, R.E. Theory and applications of the Delphi technique: A bibliography (1975-1994). J. Technol. Forecast. Soc. Chang. 1996, 53, 185-211. [CrossRef]

71. Hinks, J.; McNay, P. The creation of a management-by-variance tool for facilities management performance assessment. Facilities 1999, 17, 31-53. [CrossRef]

72. Bradley, L.; Stewart, K. A Delphi study of the drivers and inhibitors of Internet banking. Inter. J. Bank Mark. 2002, 20, 250-260. [CrossRef]

73. Orndoff, C.J.W. Promising new tool for stakeholder interaction. J. Archit. Eng. 2005, 11, 139-146. [CrossRef]

74. Padel, S.; Midmore, P. The development of the European market for organic products: Insights from a Delphi study. Br. Food J. 2005, 107, 626-647. [CrossRef]

75. Bendaña, R.; del Caño, A.; de la Cruz, M.P. Contractor selection: Fuzzy control approach. Can. J. Civ. Eng. 2008, 35, 473-486. [CrossRef]

76. Yeung, J.F.Y.; Chan, A.P.C.; Chan, D.W.M. Developing a performance index for relationship-based construction projects in Australia: Delphi study. J. Manag. Eng. 2009, 25, 59-68. [CrossRef]

77. Lucko, G.; Rojas, E.M. Research validation: Challenges and opportunities in the construction domain. J. Constr. Eng. Manag. 2010, 136, 127-135. [CrossRef]

78. Hallowell, M.R.; Gambatese, J.A. Qualitative research: Application of the Delphi method to CEM research. J. Constr. Eng. Manag. 2010, 136, 99-107. [CrossRef]

79. Weidman, J.E.; Miller, K.R.; Christofferson, J.P.; Newitt, J.S. Best practices for dealing with price volatility in commercial construction. Inter. J. Constr. Edu. Rev. 2011, 7, 276-293. [CrossRef]

80. Mitchell, V.; McGoldrick, P.J. The role of geodemographics in segmenting and targeting consumer markets: A Delphi study. Eur. J. Mark. 1994, 28, 54-72. [CrossRef]

81. Chong, H.Y.; Zin, R.M. Application of the Delphi into construction law research. Inter. J. Interdiscip. Soc. Sci. 2010, 5, 200-206. [CrossRef]

82. Gunhan, S.; Arditi, A. Factors affecting international construction. J. Constr. Eng. Manag. 2005, 131, $273-282$. [CrossRef]

83. Jones, J.; Hunter, D. Qualitative research: Consensus methods for medical and health services research. BMJ 1995, 311, 376-380. [CrossRef] [PubMed]

84. Hughes, R. Definitions for public health nutrition: A developing consensus. J. Public Health Nutr. 2003, 6, 615-620. [CrossRef]

85. Kumar, S.; Kumar, N.; Vivekadhish, S. Millennium development goals (MDGS) to sustainable development goals (SDGS): Addressing unfinished agenda and strengthening sustainable development and partnership. Ind. J. Community Med. 2016, 41, 1-4. [CrossRef] [PubMed]

86. Battersby, J. MDGs to SDGs-New goals, same gaps: The continued absence of urban food security in the post-2015 global development agenda. J. Afr. Geogr. Rev. 2017, 36, 115-129. [CrossRef]

87. WHO. Health in 2015: From Millennium Development Goals to Sustainable Development Goals. 2015. Available online: https:/apps.who.int/iris/bitstream/handle/10665/200009/9789241565110_eng.pdf (accessed on 21 April 2019).

88. Carl, D.; Clive, G. Doing biopolitics differently? Radical potential in the post-2015 MDG and SDG debates. Globalizations 2015, 12, 597-612.

89. Li, L.; Shefali, O.; Dan, H.; Yue, C.; Jamie, P.; Jun, Z.; Joy, E.L.; Simon, C.; Colin, M.; Robert, E.B. Global, regional, and national causes of under-5 mortality in 2000-15: An updated systematic analysis with implications for the sustainable development goals. Lancet 2016, 388, 3027-3035. [CrossRef]

90. ASEAN. ASEAN Cooperation on Environmentally Sustainable City (ESC). The Introduction. Available online: https://environment.asean.org (accessed on 21 January 2019). 
91. ASEAN. Annex C-Environmentally Sustainable City (ESC) Key Indicators. Available online: http: //environment.asean.org/wp-content/uploads/2017/01/Key-Indicators_2017-Endorsed.pdf (accessed on 14 January 2019).

92. Han, S.M.; Lee, M.H. Indicators for the development and management of sustainable cities: Focusing on the goal 11 of UN sustainable development goals. J. Korean R. Dev. Assoc. 2017, 29, 1-24. (In Korean)

93. Royal Government of Cambodia. Press OCM. Available online: http://pressocm.gov.kh/en/minister (accessed on 27 April 2019).

94. Schumann, A. Using Outcome Indicators to Improve Policies: Methods, Design Strategies and Implementation. OECD Regional Development Working Papers, 2016, 02. Available online: https://doi.org/10.1787/ 5jm5cgr8j532-en (accessed on 27 April 2019).

(C) 2019 by the authors. Licensee MDPI, Basel, Switzerland. This article is an open access article distributed under the terms and conditions of the Creative Commons Attribution (CC BY) license (http://creativecommons.org/licenses/by/4.0/). 